\title{
AVALIAÇÃO DE MICOTOXINAS EM GRÃOS DE MILHO NOS ESTÁDIOS FENOLÓGICOS PRÓXIMOS À COLHEITA
}

\section{RUDIMAR MOLIN}

Engenheiro Agrônomo

Orientador: Prof. Dr. ANTONIO LUIZ FANCELLI

Dissertação apresentada à Escola Superior de Agricultura "Luiz de Queiroz", Universidade de São Paulo, para obtenção do título de Mestre em Agronomia, Área de Concentração: Fitotecnia.

\section{PIRACICABA}

Estado de São Paulo - Brasil

Novembro - 1999 
Dados Internacionais de Catalogação na Publicação (CIP) DIVISĀo DE BIBLIOTECA E DOCUMENTAÇĀO - Campus "Luiz de Queiroz"/USP

Molin, Rudimar

Avaliação de micotoxinas em grãos de milho nos estádios fenológicos próximos à colheita / Rudimar Molin. - - Piracicaba, 1999.

$68 \mathrm{p}$.

Dissertação (mestrado) - - Escola Superior de Agricultura Luiz de Queiroz, 1999. Bibliografia.

1. Aflatoxina 2. Controle 3. Desoxinivalenol 4. Grão de milho 5. Micotoxina 6. Ocorrência 7. Ocratoxina 8. Toxina T-2 9. Zearalenona I. Título

CDD 633.15

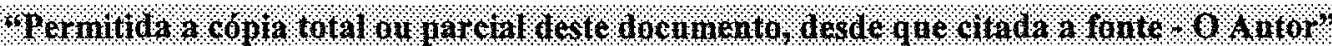


DEDICO

À minha esposa e aos meus filhos.

Aos meus pais e aos meus irmãos. 


\section{AGRADECIMENTOS}

À Deus, pela humildade concedida na leitura e interpretação de parte de sua obra maior;

Aos Cooperados das Cooperativas Agropecuárias Arapoti Ltda., Batavo Ltda. e Castrolanda Ltda. que, através de suas Lideranças, confiaram recursos e esta missão;

Ao CNPq-RHAE, pelo apoio financeiro concedido;

Às equipes de trabalho da Fundação $\mathrm{ABC}$ para Assistência e Divulgação Técnica Agropecuária e do laboratório de análises de micotoxinas da Batávia S.A., pelo empenho e dedicação ao trabalho;

Aos Professores da Escola Superior de Agricultura "Luiz de Queiroz", pelo ensino;

Aos Colegas, pela amizade. 


\section{SUMÁRIO}

Página

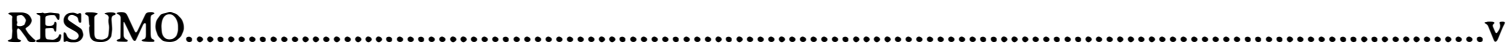

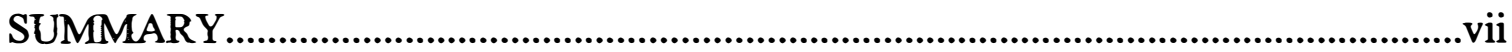

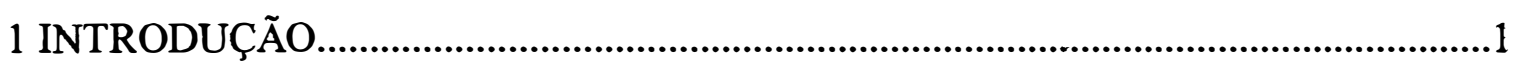

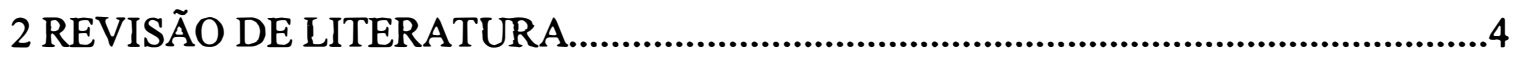

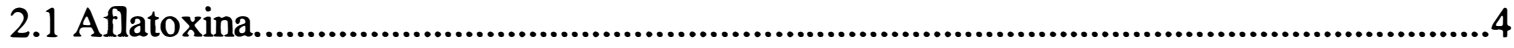

2.1.1 Fungos toxigênicos de maior importância.............................................................4

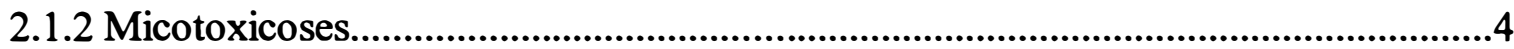

2.1.3 Condições favoráveis para a biossíntese ...........................................................

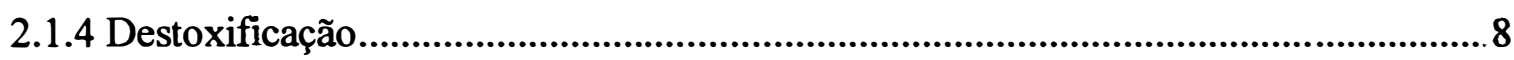

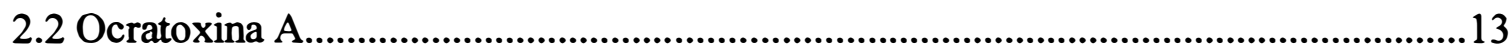

2.2.1 Fungos toxigênicos de maior importância..............................................................13

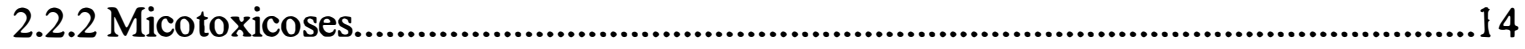

2.2.3 Condições favoráveis para a biossíntese ..............................................................14

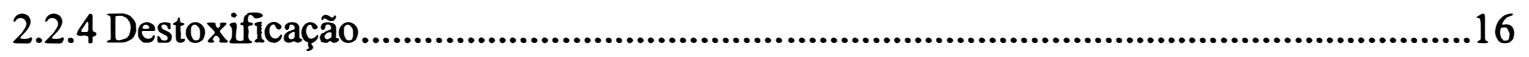

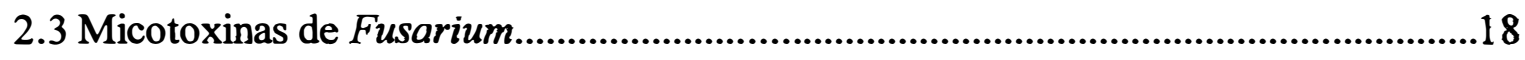

2.3.1 Fungos toxigênicos de maior importância................................................................18

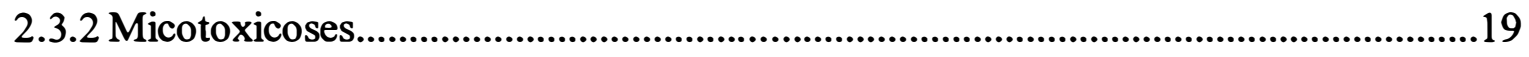

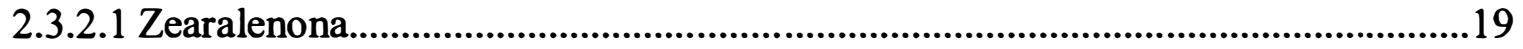

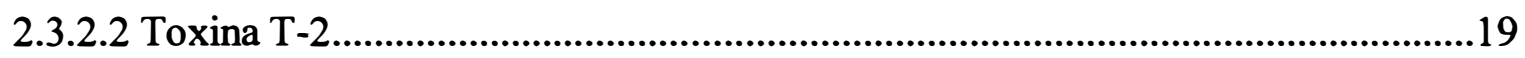

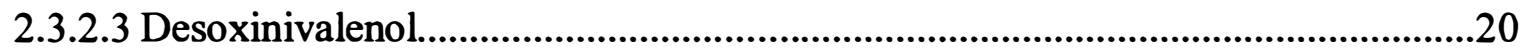

2.3.3 Condições favoráveis para a biossíntese............................................................20

2.3.3.1 Zearalenona.........................................................................................................20

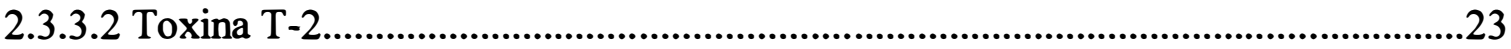

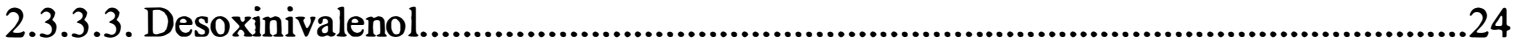

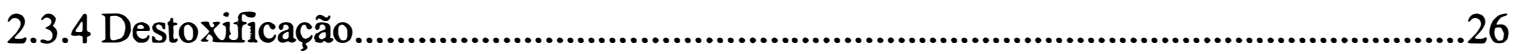

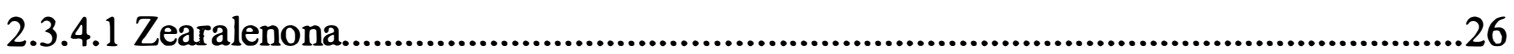

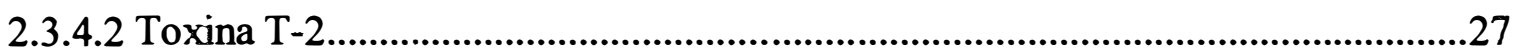




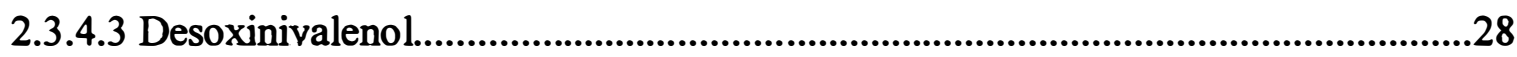

2.4 Ocorrência de micotoxinas em milho, no Brasil....................................................29

2.5 Prevenção de micotoxinas no campo: aspectos gerais.............................................30

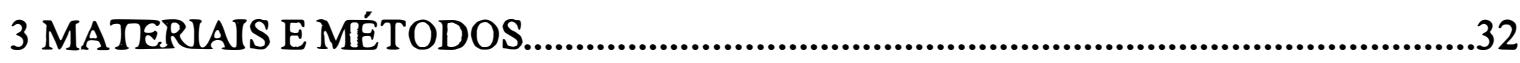

3.1 Delineamento experimental, coleta e preparo das amostras....................................32

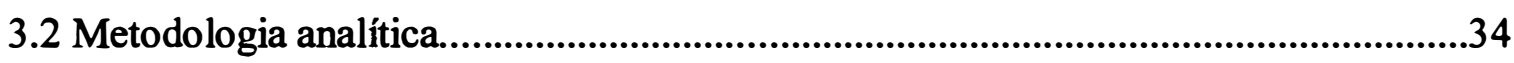

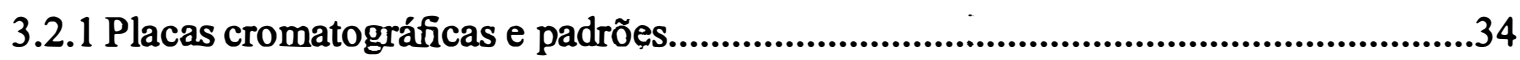

3.2.2 Extração das micotoxinas e clarificação dos extratos.............................................35

3.2.2.1 Aflatoxinas $B_{1}, B_{2}, G_{1}$ e $G_{2}$, ocratoxina $A$ e zearalenona...................................35

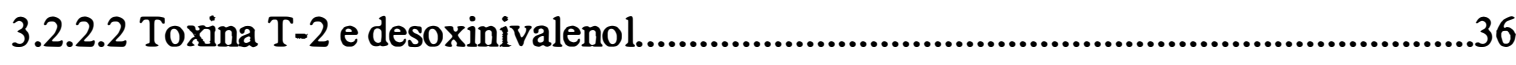

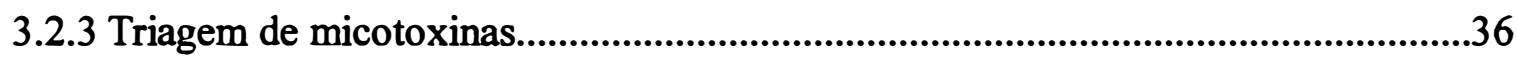

3.2.3.1 Aflatoxinas $B_{1}, B_{2}, G_{1}$ e $G_{2}$, ocratoxina $A$ e zearalenona..................................36

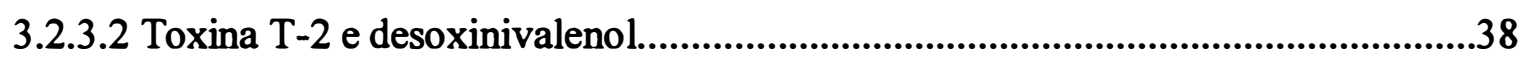

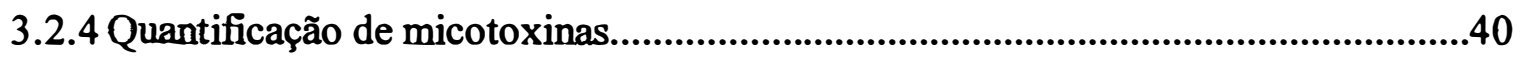

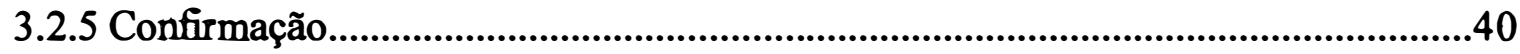

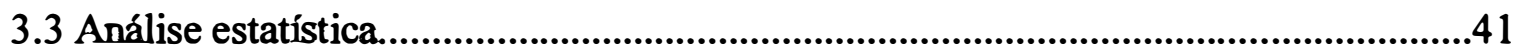

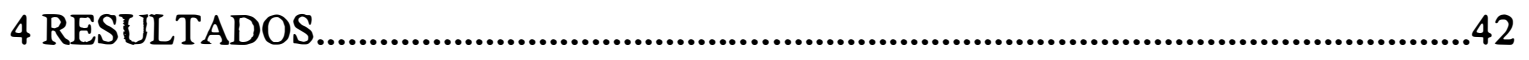

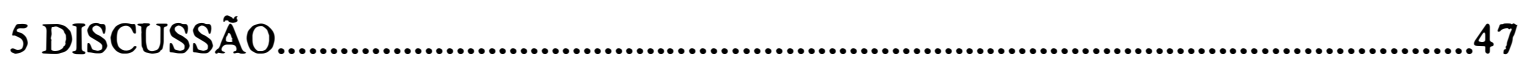

5.1 Considerações finais..........................................................................................51

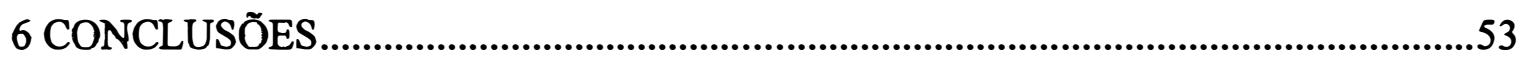

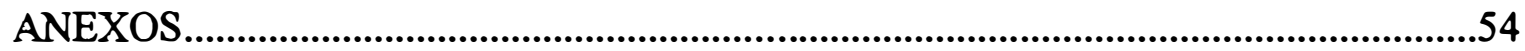

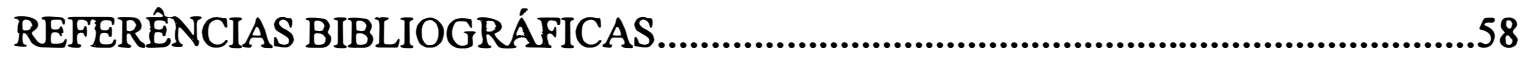




\title{
AVALIAÇÃO DE MICOTOXINAS EM GRÃOS DE MILHO NOS ESTÁDIOS FENOLÓGICOS PRÓXIMOS À COLHEITA
}

\author{
Autor: RUDIMAR MOLIN \\ Orientador: Prof. Dr. ANTONIO LUIZ FANCELLI
}

\section{RESUMO}

O presente trabalho teve por objetivo avaliar a ocorrência de aflatoxinas, ocratoxina A, zearalenona, desoxinivalenol e toxina T-2 em grãos de milho, a partir do estádio fenológico 8/9 (formação de "dentes"-grãos para ensilagem de plantas inteiras), e o estabelecimento de estratégias de colheita, visando o controle de micotoxinas por evasão, abrangendo a colheita para ensilagem de plantas inteiras e grãos úmidos e a colheita de grãos para diversas finalidades. As referidas micotoxinas podem ser tóxicas aos animais envolvidos na cadeia alimentar do Homem e diretamente ao Homem, dependendo da freqüência e quantidade ingerida. Desta maneira, os subprodutos de origem animal e os produtos e subprodutos de origem vegetal podem se constituírem em fonte de contaminação de micotoxinas para o Homem. O milho é um dos componentes utilizados no arraçoamento animal e na alimentação humana A pesquisa brasileira reporta a ocorrência dessas micotoxinas em grãos de milho no pós-colheita e em seus subprodutos. Para a avaliação das micotoxinas, foram coletadas no estado do Paraná, Brasil, 90 amostras de grãos, em duas lavouras de milho, no ano agrícola 1997/98, e em cinco épocas distintas, ou seja, no estádio fenológicos 8/9, final do estádio fenológico 9 (grãos “duros"-grãos para ensilagem de plantas inteiras), estádio fenológico 10 (maturidade fisiológica-ensilagem de grãos úmidos) e 10 e 20 dias após o estádio fenológico 10, respeitando-se intervalo de 10 dias entre as amostragens. As unidades de amostragem foram dispostas em delineamento experimental de blocos ao acaso, com nove repetições. As micotoxinas foram determinadas por cromatografia em camada delgada, cujos níveis de detecção foram 1, 4, 100, 80 e $100 \mathrm{ng} / \mathrm{g}$, para aflatoxinas, 
ocratoxina A, zearalenona, desoxinivalenol e toxina $T-2$, respectivamente. As aflatoxinas, ocratoxina A e zearalenona foram extraídas e clarificadas simultaneamente através da metodologia proposta por Soares \& Rodriguez-Amaya, com pequenas modificações. A micotoxina desoxinivalenol e a toxina T-2 também foram extraídas e clarificadas simultaneamente, porém, utilizando-se da metodologia proposta por Romer, modificada. Os dados obtidos não seguem a distribuição normal, mesmo que transformados, bem como não se enquadram em outros modelos padrões, tendo sido utilizada a análise descritiva. Observou-se predominância de zearalenona e desoxinivalenol, em níveis máximos de $1.714 \mathrm{ng} / \mathrm{g}$ e $272 \mathrm{ng} / \mathrm{g}$, respectivamente, não sendo detectado ocratoxina A e toxina T-2. Das aflatoxinas, somente a $B_{1}$ ocorreu em apenas duas amostras, em níveis entre 1 e 2 ng/g. De acordo com os resultados obtidos, verificou-se contaminação de grãos de milho por aflatoxinas após o estádio fenológico 10. A zearalenona foi detectada a partir do final do estádio fenológico 9 e o desoxinivalenol a partir do estádio fenológico 8. Na cultura de milho, o método de controle de micotoxinas por evasão não é seguro, necessitando do desenvolvimento e/ou da utilização de outras técnicas, em conjunto, para evitar a contaminação de grãos de milho por micotoxinas, no campo, especialmente, àquelas produzidas por Fusarium spp. 


\section{EVALUATION OF MICOTOXINS IN CORN GRAINS IN FENOLOGIC ST AGES CLOSE TO THE CROP}

Author: RUDIMAR MOLDN

Adviser: Prof. Dr. ANTONIO LUIZ FANCELLI

\section{SUMMARY}

The present work aimed to evaluate the occurrence of aflatoxins, ochratoxin A, zearalenone, deoxynivalenol and toxin T-2 in corn grains, starting from the fenologic stage 8/9 (formation of "dent"-grains for silage of whole plants), and the establishment of crop strategies, seeking the mycotoxins control for escape, embracing the crop for silage of whole plants and humid grains and the crop of grains for several purposes. Referred them mycotoxins can be toxicant to the animals involved in the Man's food chain and directly to Man, depending on the frequency and ingestion dose. Thus, animal and vegetal products and by-products may constitute in a source of mycotoxins contamination for the Man. Corn is one of the components used in the animal feeds and in human foods. The Brazilian research has reported the occurrence of those mycotoxins in corn kernels in the post-harvest and in its by-products. For the evaluation of the occurrence of mycotoxins, 90 samples of kernels were collected in the state of Paraná, Brazil, from two corn crops, in the agricultural year of 1997/98, and in five different times, namely in the fenologic stages 8/9, final of the fenologic stage 9 (grains "hard"grains for silage of whole plants), fenologic stage 10 (maturity physiologic-silage of moist grains) and 10 and 20 days after the fenologic stage 10, with 10-days intervals between samplings. The experiment was design in random blocks, with nine repetitions. The mycotoxins were determined by thin layer chromatography, with detection levels of 1, 4, 100, 80 and $100 \mathrm{ng} / \mathrm{g}$, for aflatoxins, ochratoxin A, zearalenone, deoxynivalenol and toxin T-2, respectively. For aflatoxins, ochratoxin A and zearalenone the method Soares \& Rodriguez-Amaya with small modifications. For deoxynivalenol and the toxin 
T-2 the method of Romer, modified was used of. The obtained data did not follow the normal distribution, even if transformed, as well as did not fit in other standard models and thus the descriptive analysis was applied. Zearalenone and deoxynivalenol were prevalent, in maximum levels of $1.714 \mathrm{ng} / \mathrm{g}$ and $272 \mathrm{ng} / \mathrm{g}$, respectively, not being detected ochratoxin A and T-2 toxin. Of the aflatoxins only $\mathrm{B}_{1}$ occurred in only two samples, in levels between 1 and $2 \mathrm{ng} / \mathrm{g}$. According to the obtained results, contamination of corn kernels with aflatoxins was verified after the fenologic stage 10 . Zearalenone was detected starting from the end of the fenologic stage 9 and deoxynivalenol starting from the fenologic stage 8. In the corn crop, the evasion method for mycotoxins control is not efficient needing the development and/or the use of other techniques, together, to avoid the contamination of field corn by mycotoxins especially, those produced by Fusarium spp. 


\section{INTRODUÇÃO}

O milho é uma cultura de grande importância econômica e social no mundo, correspondendo a, aproximadamente, $11,0 \%$ da produção dos principais grãos de cereais de inverno e verão cultivados no mundo e ocupando $10,0 \%$ da área total das culturas anuais de verão, bem como é o cereal de maior rendimento cultural (FAO, 1996 e FAO,1998).

O Brasil é o terceiro maior produtor de milho no cenário internacional, contribuindo com $5,5 \%$ do total da produção em $25 \%$ da área brasileira de culturas anuais de verão (FAO, 1996).

Segundo a ABMMLHO ${ }^{1}$, no período de 1993/94 a 1996/97, em torno de $15 \%$ do total de milho consumido no Brasil destinou-se ao consumo humano direto (2\%-enlatados e 13\%-subprodutos da moagem); $52 \%$ foi industrializado nas fábricas de rações para atender a demanda da produção de alimentos de origem animal (30\% para avicultura, $16 \%$ para suinocultura e $6 \%$ para outros animais); $1 \%$ foi consumido na produção de sementes e $32 \%$ permaneceu nas propriedades rurais, principalmente naquelas exploradas na forma de subsistência, acrescido das perdas na cadeia produtiva.

De acordo com Company (1984), a referida cultura tem uma ampla capacidade de adaptação, sendo de grande importância para a alimentação humana no presente e no futuro, principalmente no sentido de garantir o incremento da produção de alimentos em função do aumento de população e do esgotamento das fronteiras agrícolas. Para Monteiro et al. (1992) o milho apresenta acentuada dispersão geográfica no Brasil, sendo produzido, praticamente, em todo território nacional.

\footnotetext{
${ }^{1}$ ABIMILHO. Associação Brasileira de Indústrias de Milho. Comunicação pessoal, 1998.
} 
Todavia, muitos são os problemas enfrentados por essa cuttura, dentre os quais merecem especial destaque a incidência de pragas, doenças e plantas daninhas. As principais doenças associadas à cultura de milho, no Brasil, são causadas por vírus, bactérias e fungos, incluindo os do gênero Aspergillus, Penicillium e Fusarium (Pereira, 1997). Esses fungos, em determinadas condições, podem infectar os grãos, ainda no campo (Williams \& McDonald, 1983) e, além dos danos diretos do parasitismo, são capazes de produzir metabólitos secundários tóxicos denominados de micotoxinas, as quais diferem na sua forma química de acordo com o substrato e condições que são produzidas, no grau de toxicidade e nos efeitos tóxicos, ou seja, micotoxicoses causadas em animais e no Homem (Agrios, 1997).

As micotoxinas de importância na agricultura são as aflatoxinas, ocratoxina $\mathrm{A}$, zearalenona, desoxinivalenol (DON ou vomitoxina), toxina $\mathrm{T}-2$ e fumonisinas (Miller, 1995), as quais apresentam ocorrência mundial, podendo, também, serem transportadas em lotes de grãos contaminados, para as regiões em que não há condições favoráveis para a sua síntese (Lazzari, 1997).

Assim, de acordo com Nelson et al. (1993), a ocorrência de micotoxicoses depende da interação de muitos fatores, destacando-se entre eles a infecção e a colonização da planta hospedeira por fungos produtores de micotoxinas; ambiente favorável ao desenvolvimento da doença; habilidade genética do patógeno na produção de micotoxinas; ambiente favorável para produzir e acumular quantidades suficientes de micotoxinas, nas plantas hospedeiras, capazes de causar micotoxicoses nos consumidores e o consumo de quantidades suficientes de hospedeiros ou partes contaminadas por micotoxinas.

Não há, ainda, métodos físicos, químicos e biológicos eficientes para destoxificação de lotes de produtos contaminados em larga escala, que podem contribuir para minimizar os efeitos das micotoxinas. Existe pois, a probabilidade, de pelo menos parte das micotoxinas preexistentes, ou em função da utilização de subprodutos obtidos nos processos de industrialização com altas concentrações de toxinas, seguirem a cadeia alimentar que envolve os animais domésticos e o Homem, podendo causar-lhes micotoxicoses. Desta forma, a prevenção de sua ocorrência é o mais recomendado. 
Assim, mostra-se crescente a preocupação dispensada por parte das indústrias brasileiras com a qualidade da matéria prima utilizada na fabricação de rações destinadas a alimentação de animais domésticos. De acordo com Menegazzo \& Lazzari (1996), pode-se citar o exemplo da PERDIGÃO, a qual destina lotes de milho para fabricação de rações para aves e suínos, de acordo com seu padrão de micotoxinas, cujo limite máximo é de $20 \mathrm{ng} / \mathrm{g}$ para aflatoxinas, $500 \mathrm{ng} / \mathrm{g}$ para zearalenona e $2.000 \mathrm{ng} / \mathrm{g}$ para desoxinivalenol.

Dentro deste contexto, o presente trabalho propôs-se a avaliar a ocorrência de aflatoxinas, ocratoxina $\mathrm{A}$, zearalenona, desoxinivalenol e toxina $\mathrm{T}-2$ em grãos de milho, no sistema de plantio direto, em estádios fenológicos próximos da colheita, bem como objetivou o estabelecimento de estratégias de colheita, visando o controle por evasão (retirada do produto do campo antes de ser contaminado, ou pelo menos com menor probabilidade de ocorrência), assegurando assim, apenas a necessidade de implementação de medidas para manutenção da qualidade de grãos, da colheita até o consumo final. 


\section{REVISÃO DE LITERATURA}

\subsection{Aflatoxina}

\subsubsection{Fungos toxigênicos de maior importância}

De acordo com a citação de Gourama \& Bullerman (1995), o Aspergillus flavus, A. flavus subsp. parasiticus e o A. nomius são importantes produtores de aflatoxinas. Algumas linhagens de $A$. flavus não são toxigênicas, enquanto outras têm habilidade de produzir aflatoxinas $\mathrm{B}_{1}$ e $\mathrm{B}_{2}$. $\mathrm{O}$ A flavus subsp. parasiticus produz aflatoxinas $\mathrm{B}_{1}, \mathrm{~B}_{2}$, $\mathrm{G}_{1}$ e $\mathrm{G}_{2}$ com maior estabilidade em relação ao $A$. flavus. $\mathrm{O}$ milho, amendoim, caroço de algodão e algumas espécies de nozes são produtos afetados pelas aflatoxinas. $\mathrm{O}$ A. flavus geralmente é encontrado em regiões de clima com temperaturas mais baixas, cuja maior parte da produção de conídios ocorre no ar em relação ao solo, estando mais associado a cultura de milho, enquanto o $A$. subsp. parasiticus adapta-se melhor em regiões mais quentes e, freqüentemente, é encontrado associado ao solo, sendo o contaminante mais comum do amendoim.

\subsubsection{Micotoxicoses}

A Intermational Agency for Research on Cancer (IARC) declarou, em 1987, que a aflatoxina $B_{1}$ possuí o mais alto grau de potencial carcinogênico para o Homem, com base nos estudos realizados em animais. A aflatoxina $B_{1}$ possuí o maior grau de toxicidade para animais, seguida da $M_{1}, G_{1}, B_{2}$ e $G_{2}$ (Gourama \& Bullerman, 1995). A 
aflatoxina $\mathrm{M}_{1}$ é o principal metabólito da $\mathrm{B}_{1}$, a qual pode ser encontrada em leite bovino (Diekman \& Green, 1992).

Lazzari (1995) cita que as aflatoxinas são carcinogênicas, teratogênicas, e mutagênicas para o Homem, bovinos, ovinos, aves, suínos e coelhos. Para Jones et al. (1982) as referidas micotoxinas têm efeito imunosupressor em galinhas, interferem no sistema renal, aumentam o consumo de proteínas, diminuem a pigmentação de carcaças aumentando-lhes a condenação, alteram o metabolismo de vitaminas, diminuem a produção de ovos, reduzem o crescimento e a conversão alimentar e incrementam a mortalidade.

Fiorentin et al. (1986), constataram um surto de aflatoxicose em suínos, que estava associado à ingestão de ração, cujo componente milho continha $2.000 \mathrm{ng} / \mathrm{g} \mathrm{de}$ aflatoxina $\mathrm{B}_{1}$, além da presença de $A$. flavus e $A$. parasiticus, no município de Concórdia, SC, e Santos et al. (1986) relataram um surto de aflatoxicose em suínos na Zona da Mata, no estado de Minas Gerais.

\subsubsection{Condições favoráveis para a biossíntese}

A biossíntese de aflatoxinas ocorre em ambientes com temperaturas entre $8^{\circ} \mathrm{C}$ e $42^{\circ} \mathrm{C}$ (ótimo de 25 a $28^{\circ} \mathrm{C}$ ), temperaturas alternadas de 32 a $38^{\circ} \mathrm{C} / 21$ a $26^{\circ} \mathrm{C}$ e umidade elevada nos substratos. Plantas estressadas por temperaturas altas e ambientes com baixa precipitação pluvial; a ação de insetos sobre os grãos; a ação mecânica sobre os grãos durante a colheita; o estádio de maturidade dos grãos de milho e a presença de microorganismos também podem interferir na síntese das toxinas.

Gourama \& Bullerman (1995) revisando trabalhos de diversos autores, relatam que o real papel da produção de toxinas por fungos ainda não é bem conhecida e que a síntese das aflatoxinas em laboratório, resulta da combinação da espécie do fungo, do substrato e do ambiente, sendo afetada por fatores físicos (temperatura, $\mathrm{pH}$, umidade relativa, luz, aeração e nível de gases na atmosfera), nutricionais e biológicos. A temperatura ótima para produção de aflatoxinas pelo $A$. flavus, em meio de cultura, é de $25^{\circ} \mathrm{C}$, enquanto para o $A$. flavus subsp. parasiticus oscila entre 25 a $35^{\circ} \mathrm{C}$. Em 
temperaturas abaixo de $8^{\circ} \mathrm{C}$ e acima de $42^{\circ} \mathrm{C}$ dificilmente há produção de aflatoxinas; no entanto, a faixa ótima mais aceita é de 25 a $28^{\circ} \mathrm{C}$.

Ainda de acordo com o relato dos mesmos autores, a umidade relativa do ar mínima para produção de aflatoxinas varia entre 83 e $88 \%$, ocorrendo incrementos até $99 \%$. O processo de desenvolvimento do fungo e de produção de aflatoxina é aeróbio, sendo que o aumento de $\mathrm{CO}_{2}$, de 20 para $100 \%$ no ambiente de crescimento e de desenvolvimento, inibe gradativamente a produção de aflatoxinas. A presença de A. niger, Rhizopus oligosporus e Neurospora spp. também inibe a produção dessas toxinas.

Jones et al. (1980) demonstraram que a infecção dos estilo-estigmas de milho por A. flavus é favorecida por temperaturas altas $\left(32 \mathrm{a} 38^{\circ} \mathrm{C}\right)$ seguida de temperaturas baixas $\left(21\right.$ a $\left.26^{\circ} \mathrm{C}\right)$.

Bosque (1996) relata que das práticas agronômicas avaliadas (escolha de genótipos de milho tolerantes à podridões de espiga e à insetos, população de plantas, irrigação, controle químico de insetos de espigas e época de semeadura) a época de semeadura, em que a média de temperatura mínima do período entre o florescimento do milho e a maturidade foi inferior a $16^{\circ} \mathrm{C}$, não favoreceu a produção de aflatoxinas na pré-colheita (grãos com 20 a $25 \%$ de umidade), mesmo com espigas danificadas por insetos ou artificialmente. Quando o periodo anteriormente citado, por influência da época de semeadura, coincidiu com temperatura mínima média entre 22 e $24^{\circ} \mathrm{C}$, ocorreu produção de aflatoxinas na pré-colheita, obtendo-se correlação positiva entre espigas danificadas por insetos e concentração de micotoxinas. Os outros fatores testados tiveram influência não significativa, com exceção do estresse por falta de água, o qual não pode ser avaliado efetivamente, por influência de chuvas ocorridas durante a pesquisa.

De acordo com Miller, (1995) a infecção dos estilo-estigmas, sem o auxílio de insetos, em câmara de crescimento, levou à colonização de grãos somente quando o milho foi submetido a estresse por temperatura alta.

O aumento da síntese de aflatoxinas nas áreas de produção de milho do sudeste dos EUA foi associada à alta temperatura e à baixa precipitação pluvial, especialmente 
no período compreendido entre o florescimento do milho e o final do estádio de grãos pastosos (Lillehoj et al., 1978 e Zuber \& Lillehoj, 1979).

$\mathrm{O}$ total de esporos de $A$. flavus presentes no ar, bem como a fração esporos viáveis, coletados em armadilhas, com freqüência semanal, correlacionaram-se negativamente com a precipitação (chuva e/ou irrigação) e com o periodo de molhamento de folhas. A contaminação por aflatoxina $\mathrm{B}_{1}$ pode ser atribuída, pelo menos, à coincidência de alta abundância de esporos e incremento do estresse por falta de água, durante o período de enchimento de grãos de milho, com temperaturas favoráveis à produção da toxina. Fatores que influenciam o estresse de plantas como a falta de água e a semeadura tardia estão fortemente associados ao incremento da infecção de $A$. flavus e à produção de micotoxinas, sugerindo que a redução do índice de área foliar facilitaria a deposição de esporos. A contaminação de aflatoxina com o atraso da colheita variou de local para local e de ano para ano, sendo que em um local e em um ano, sem irrigação, houve incremento de aflatoxina com o atraso da colheita (Jones et al., 1981).

Os trabalhos de Kawashina et al. (1993), sugerem que a maturidade de grãos de milho (colheita realizada de $28,9 \%$ até $17,5 \%$ de umidade), de alguma maneira, pode influenciar positivamente na produção de aflatoxinas $\mathrm{B}_{1}$, apesar da menor infecção por A. flavus. Concluíram também que a debulha mecânica foi o processo mais relacionado com o início da infecção com $A$. flavus.

Bilgrami et al. (1992) encontraram aflatoxina $B_{1}$ em 69 amostras de grãos analisadas, as quais foram divididas em classes de espigas sadias (10 amostras) e espigas danificados por insetos (48 amostras) ou espigas danificadas por pássaros (11 amostras), sendo que as concentrações mais altas da toxina estavam presentes nos grãos das espigas danificadas por insetos.

Há evidências de que o estresse por seca favorece a contaminação de milho por aflatoxinas bem como a falta ou excesso de nitrogênio. Altas temperaturas (entre 36 e $38^{\circ} \mathrm{C}$ ) são ótimas para o crescimento do $A$. flavus (Payne, 1992) enquanto que acima de $30 \mathrm{a} 34^{\circ} \mathrm{C}$ a planta de milho apresenta desenvolvimento reduzido, cessando-o à $40-44^{\circ} \mathrm{C}$ (Andrade et al., 1996). Temperaturas noturnas elevadas (acima de $22^{\circ} \mathrm{C}$ ) e 
diumas máximas de $34^{\circ} \mathrm{C}$ parecem ter mais influência no desenvolvimento de aflatoxinas em milho, no campo, que a umidade ou a precipitação, sendo verificado que o período de estresse mais crítico para o milho foi de 20 a 60 dias após a emergência total dos estilo-estigmas (Payne, 1992).

Nas avaliações mensais de amostras de milho coletadas e armazenadas em Ribeirão Preto, SP, em sacos de $60 \mathrm{~kg}$, durante um ano, com umidade entre 12,3 e 17,8\%; umidade relativa do ar entre 64 a 97,5\%; temperatura média do ar mínima de $18,4^{\circ} \mathrm{C}$ e máxima de $24,1^{\circ} \mathrm{C}$ e chuva próximo a $337 \mathrm{~mm}$, foram isolados, em ordem decrescente de freqüência, Fusarium spp, Penicillium spp e Aspergillus spp. As três espécies predominantes de Aspergillus em ordem decrescente, foram o $A$. flavus ( predominante em grãos com 12,0 a 14,0\% de umidade), $A$. niger (predominante em amostras de 12,0 a $14,0 \%$ de umidade) e $A$. parasiticus (predominante em amostras com 14,3 a $17,8 \%$ de umidade). Todavia, não houve correlação significativa entre a população de Aspergillus com os fatores abióticos, tendo sido detectado $500 \mathrm{ng} / \mathrm{g}$ de aflatoxina $B_{1}$ somente em uma amostra (Pozzi et al. 1995).

\subsubsection{Destoxificação}

Os métodos físicos de destoxificação envolvem a degradação de micotoxinas (Doyle, et al., 1982), ou redução da toxicidade (Ramos \& Hernãndez, 1991), através do calor, irradiação (gama, luz visível e ultravioleta), adsorsão (Doyle, et al., 1982 e Samarajeewa et al., 1990), seleção de grãos sadios com cor característica e diluição com grãos sadios, ressaltando-se que a adsorsão, em alguns casos, tem sido classificada como processo químico de destoxificação (Ramos \& Hernãndez, 1991). Os métodos químicos compreendem a utilização de agentes de hidrólise, alcalinos e ácidos (amônia, hidróxido de sódio, bicarbonato de sódio, hidróxido de cálcio), agentes de oxidação (peróxido de hidrogênio, ozônio, bisulfito), vitaminas (Doyle, et al., 1982 e Samarajeewa et al., 1990) e agentes clorantes, principalmente o cloro (Samarajeewa et al., 1990 e Ramos \& Hernãndez, 1991), enquanto que nos processos biológicos as toxinas são degradadas através do emprego de microorganismos (Doyle, et al., 1982). 
As operações de processamento de alimentos (período e condições de armazenamento, seleção, moagem seca e úmida de milho, moagem de farinha, torrefação, panificação, fermentação, processos de secagem, esterilização, cozimento, fervura, peletização e pasteurização) apresentam eficiência variada na redução dos teores iniciais de micotoxinas e dependem de fatores tais como a natureza do processo, a natureza e a matriz do alimento (grão inteiro, farelo, farinha), conteúdo de água e aditivos, natureza da micotoxina e nível de contaminação (Scott, 1984).

A aflatoxina $B_{1}$ sólida é estável ao calor seco até o ponto de fusão $\left(260^{\circ} \mathrm{C}\right)$, e se decompõe a $269^{\circ} \mathrm{C}$ porém, necessita mais de $300^{\circ} \mathrm{C}$ para ser degradada em determinados alimentos (Samarajeewa et al., 1990). As aflatoxinas $B_{1}, B_{2}, G_{1}$ e $G_{2}$, genericamente, são moderadamente estáveis nos processos que utilizam calor, sendo passíveis de redução, na maioria dos casos de, aproximadamente, 20 a 50\% do teor inicial (Scott, 1984).

O torrefação de café com $200^{\circ} \mathrm{C}$, o processo de extração de óleo e o processo de cozimento na água, reduziram a aflatoxina $\mathrm{B}_{1}$ em $94 \%, 74$ a $100 \%$ e $82 \%$, respectivamente, enquanto que no processo de destilação a aflatoxina $B_{1}$ não foi arrastada para o álcool, porém, manteve-se no bagaço em concentrações superiores às inicias. Todavia, no processo de pasteurização de leite a aflatoxina $M_{1}$ manteve-se estável (Scott, 1984).

A extrusão termoplástica de farinha de milho com $35 \%$ de umidade, reduziu a contaminação natural de aflatoxina $B_{1}$ e $B_{2}$ acima de 50 e $90 \%$, respectivamente; contudo, apesar de não ter sido drástica, verificou-se redução também nos teores de aminoácidos (Mandarino et al., 1989)

$\mathrm{O}$ aquecimento do milho entre 160 e $180^{\circ} \mathrm{C}$ reduziu o teor de aflatoxinas, porém diminuiu significativamente os teores de lisina e metionina (Diekman \& Green, 1992).

$\mathrm{O}$ tratamento com altas temperaturas e pressão reduz o teor de aflatoxinas em torno de 73 a 100\%, porém, não é considerado meio prático para tal fim, bem como afeta a qualidade organoléptica e nutricional de alimentos, deixando dúvidas quanto à geração de outras substâncias tóxicas. Todavia, o tratamento de produtos com raios gama isoladamente não possibilita a degradação ou prevenção da formação de aflatoxinas. $\mathrm{O}$ tratamento com luz ultra violeta utilizado para a degradação de aflatoxinas, apesar de 
patenteado, não obteve grande aceitação industrial, provavelmente devido às limitações da baixa capacidade de penetração da irradiação nos alimentos e, ainda, pela presença de estreita faixa de comprimento de onda ativa, bem como pela possibilidade dos compostos primários da degradação reterem residual tóxico (Samarajeewa et al., 1990).

Ramos et al. (1996), revisando trabalhos de vários autores, relatam que a adição de adsorventes inertes não nutritivos na dieta de animais (carvão ativado, argilas com capacidade de troca cationica ${ }^{2}$, resinas de troca aniônica e resinas de troca catiônica) para seqüestrar as micotoxinas, com o objetivo de reduzir-lhes a absorção no trato gastrointestinal e evitar os efeitos tóxicos, bem como o ingresso das toxinas nos produtos animais, apresentam resultados promissores, principalmente o uso de HSCAS para aflatoxinas. Todavia, todos esses produtos, merecem maiores estudos sobre o efeito no metabolismo animal de nutrientes essenciais, em especial de vitaminas e minerais. Além disso, os seqüestrantes não possuem amplo espectro de ação, havendo evidências que os de troca catiônica adsorvem com maior eficiência as aflatoxinas e os de troca aniônica adsorvem melhor zearalenona, tricotecenos e ocratoxina $\mathrm{A}$.

Morais et al. (1993), estudaram o efeito de dois ahumíno-silicatos na proteção contra aflatoxicoses, na alimentação de frangos, por um período de 47 dias e concluíram que a aflatoxina atuou de maneira significativa, afetando negativamente o desempenho das aves, no que se refere ao peso corporal médio, ganho de peso, consumo alimentar, conversão alimentar e mortalidade.

O emprego de $0,5 \%$ de bentonita sódica natural, adicionada na ração, protegeu parcialmente os perus de corte dos efeitos negativos da aflatoxina (Santurio et al., 1998).

Contudo, o processo de limpeza seca, úmida e por densidade não foi eficaz na redução de aflatoxina $B_{1}$ em milho (Scott, 1984).

A mistura de grãos sadios com grãos contaminados, com objetivo de reduzir os níveis de contaminação por micotoxinas e as micotoxicoses, pode ser usado, no entanto, as perdas econômicas de sua adoção são desconhecidas. A principal razão para esse fato

\footnotetext{
${ }^{2}$ Bentonita, zeolita, alumino-silicato de cálcio e sódio hidratado, também conhecido por HSCAS, motmorilonitas e vermiculita-hidrobiotita purificada, composta de silicato de magnésio hidratado com conteúdos váriáveis de potássio, ferro e cálcio.
} 
está ligada à possível ocorrência de interações entre as muitas micotoxinas existentes em baixas concentrações, que pode resultar na redução do desempenho dos animais, cuja quantificação é extremamente dificultada (Diekman \& Green, 1992).

$\mathrm{O}$ processo de moagem úmida de milho concentrou a aflatoxina $B_{1}$ na fase aquosa (39 a 42\%), na porção fibrosa (30 a 38\%), no glúten (13 a 17\%), no amido (1\%) e no gérmen (6 a 10\%). Nesse mesmo processo, a zearalenona distribuí-se na fase aquosa (17 a $26 \%$ ), na porção fibrosa (15 a 19\%), no glúten (49 a 56\%), no amido ( $0 \%$ ) e no gérmen ( 9 a 11\%). Por outro lado, a toxina T-2 concentrou-se na fase aquosa (64 a $70 \%$ ), na porção fibrosa ( 9 a $11 \%$ ), no glúten ( 6 a 13\%), no amido ( 3 a $6 \%$ ) e no gérmen (8 a 12\%). No processo de moagem seca de milho houve concentração de 5 a $31 \%$ de aflatoxina $B_{1}$ na casca, 7 a $12 \%$ no farelo, 30 a $49 \%$ no gérmen, 2 a $6 \%$ na farinha grossa, 2 a $3 \%$ na farinha de baixa teor de óleo e 14 a $15 \%$ na farinha de alto teor de óleo (Scott, 1984).

O tratamento de alimentos com produtos alcalinos dispõem de poucas informações quanto ao efeito negativo em seu valor nutritivo e à presença de residuais tóxicos, sendo que algumas substâncias alcalinas, como o hidróxido de cálcio, podem contribuir para a degradação da aflatoxina $B_{1}$ a taxas superiores a $95 \%$ (Samarajeewa et al., 1990).

Assim, Ramos \& Hernåndez (1991) relatam que a eficiência relativa das substâncias alcalinas na degradação de aflatoxina $B_{1}$ a $110^{\circ} \mathrm{C}$ obedece a seguinte seqüência decrescente: hidróxido de potássio $>$ hidróxido de sódio $>$ carbonato de potássio > carbonato de sódio > bicarbonato de potássio > hidróxido de amônia > bicarbonato de sódio > carbonato de amônia.

Os autores também relatam que o tratamento de milho com $3 \%$ hidróxido de sódio a $100^{\circ} \mathrm{C}$, durante 4 minutos, degradou $93 \%$ de $\mathrm{B}_{1}$ e $\mathrm{B}_{2} \mathrm{e}$, quando ratado com $2 \%$ de hidróxido de sódio, à temperatura ambiente, foi necessário 24 horas para atingir níveis não detectáveis dessas toxinas.

A utilização de uréia, como fonte de amônia, diretamente nos componentes de ração para ingestão animal degradou 77 a $99 \%$ da toxina $B_{1}$, em laboratório, e 85\%, em experimentos de grande escala (Shantha et al., 1986). 
O tratamento de fubá, obtido de grãos de milho contaminados naturalmente com aflatoxina, mediante o uso de hidróxido de amônio e peróxido de hidrogênio, antes do processo de extrusão, reduziu parcialmente os níveis de aflatoxina $B_{1}(67,0$ e $52,8 \%$ respectivamente), diminuindo também os teores de aminoácidos presentes (Mandarino et al., 1988).

Por outro lado, evidências experimentais indicam que a amoniação não tem efeitos tóxicos para patos, perus, gạlinhas, vacas e suỉnos; contudo, pode resultar em pequeno índice de ganho de peso em galinhas e na redução de $10 \%$ da qualidade das proteínas das rações, além de contribuir para a diminuição do teor de lisina e metionina e tornar irreversível o processo de redução do grau de insaturação de lipídios (Samarajeewa et al., 1990).

A utilização de ácidos fortes pode afetar a qualidade dos alimentos e transformar a aflatoxina $B_{1}$ em $B_{2 a}$ e a $G_{1}$ em $G_{2 a}$, cuja toxicidade poderá se manter, mesmo sabendo que a $B_{2 a}$ e $G_{1 a}$ é 200 vezes menos tóxica que $B_{1}$ e $G_{1}$, respectivamente (Ramos \& Hernãndez, 1991). Esse tratamento constituí-se em alternativa de difícil viabilidade para destoxificação de "commodities" agrícolas, do ponto de vista operacional e técnico, principalmente pelo fato de degradar as toxinas parcialmente (Doyle, et al., 1982).

O tratamento de milho com $0,5,1$ e $2 \%$ de bisulfito de sódio degradou 80 a $90 \%$ da aflatoxina $B_{1}$ à temperatura ambiente (Doyle, et al., 1982). Salienta-se que o produto referido não causa mudanças drásticas na cor e em outras características do milho, porém apresenta baixa eficiência na degradação de $B_{2}$ e $G_{2}$ (Samarajeewa et al., 1990), bem como pode propiciar uma possível regeneração da toxina $B_{1}$ tratada (Ramos \& Hernãndez, 1991). O peróxido de hidrogênio proporcionou a oxidação parcial da aflatoxina $M_{1}$ no leite (Doyle, et al., 1982).

A utilização de ozônio como tratamento de produtos contaminados, constituí-se em método pouco satisfatório na degradação de aflatoxinas em torta de amendoim, o qual necessita longa duração de exposição, além de diminuir o índice de eficiência das proteínas e a disponibilidade de lisina (Dollear et al., 1968), contudo, de acordo com Ramos \& Hernãndez (1991) pode ser considerado como método eficiente para aflatoxinas $B_{1}$ e $G_{1}$ e pouco eficiente para aflatoxinas $B_{2}$ e $G_{2}$. 
Quanto à cloração, apesar de degradar até 100\% de aflatoxinas, a segurança do processo ainda é preocupante devido à presença de resíduos de cloro e a produção de gorduras e proteínas modificadas que podem apresentar toxicidade desconhecida, bem como pela redução do conteúdo de triptofanos dos alimentos (Samarajeewa et al., 1990).

A aplicação de temperaturas altas, utilizadas no processo de peletização de rações $\left(95\right.$ a $\left.100^{\circ} \mathrm{C}\right)$, em torta de amendoim previamente tratada com amônia ou hidróxido de sódio, reduziu a $\mathrm{B}_{1}$ em 89 e $69 \%$, respectivamente. Todavia, a aplicação de amônia durante o processo de peletização foi pouco efetiva na degradação da toxina, provavelmente devido à exposição da amônia ao calor durante poucos segundos (Thiesen, 1977).

O álcool etílico aquoso comercial removeu $95,3 \%$ de aflatoxinas $\mathrm{B}_{1}$ de farelo de amendoim, a $75^{\circ} \mathrm{C}$, sem afetar o teor de proteínas (Fonseca, 1994).

A lavagem de milho com água, objetivando a redução do nível de contaminação de micotoxinas hidrosolúveis, pode ser utilizada, porém é um processo moroso e caro, quando empregado em grande escala (Diekman \& Green, 1992).

O Lactobacillus spp. (L. acidophilus, L. bulgaricus e L. plantarum), bactérias produtoras de ácido lático, comercialmente utilizadas no processo de ensilagem, não afetaram o desenvolvimento de fungos aflatoxigênicos em substratos sólidos de milho e arroz, no entanto, estimularam a produção de aflatoxina $B_{1}$ em arroz (Karunaratne et al., 1990). Da mesma forma, o processo de fermentação que ocorre na ensilagem de milho não causou efeito na destoxificação da aflatoxina $B_{1}$ (Lindenfelser \& Ciegler, 1970). Por outro lado, a fase de fermentação do processo de fabricação de cerveja, segundo Scott (1984), reduziu os teores de aflatoxinas entre 73 e $82 \%$.

\subsection{Ocratoxina A}

\subsubsection{Fungos toxigênicos de maior importância}

$\mathrm{O} A$. alutaceus (anteriormente identificado como $A$. ochraceus) é a espécie mais importante que contamina cereais com ocratoxina A (Marquardt \& Frohlich, 1992), 
podendo ser isolado também em café, temperos, soja e amendoim, enquanto o Pennicillium verrucosum produz ocratoxina A, especialmente em cereais armazenados (Moss, 1996).

\subsubsection{Micotoxicoses}

Os efeitos da ocratoxina A podem variar de toxicoses crônicas até morte dos animais contaminados, dependendo da quantidade ingerida (Diekman \& Green, 1992).

A referida toxina apresenta grande potencial carcinogênico para os suínos causando-lhes nefropatia, bem como pode ser teratogênica e potente supressora do sistema imunológico em aves, atuando na redução da conversão alimentar e no aumento do índice de mortalidade. É teratogênica e carcinogênica para camundongos, teratogênica para ratos e genotóxica para células de mamíferos. Os ruminantes parecem ser menos afetados, podendo, contudo, causar-lhes depressão clínica, desidratação e redução de peso (Marquardt \& Frohlich, 1992).

De acordo com o relato do mesmo autor, a ocratoxina A pode ser encontrada nos produtos derivados de carne que contém sangue, rins e figado de suínos, além de rins, fígado e músculo de aves, apresentando baixa probabilidade de deteç̧ão no leite de ruminantes, quando esses animais são alimentados com ração contaminada.

A IARC classificou a ocratoxina A com potencial carcinogênico (grupo B) também para os seres hurnanos, com base nos estudos realizados em animais, sendo a meia vida da molécula estimada em, aproximadamente, 840 horas para o Homem (Kuiper-Goodman, 1996).

\subsubsection{Condições favoráveis para a biossíntese}

A ocratoxina pode ser biossintetisada em ambientes com temperatura entre $4 \mathrm{e}$ $37^{\circ} \mathrm{C}$ (ótimo de $24-25^{\circ} \mathrm{C}$ ) e em substratos com atividade de água superior a 0,83 (ótimo acima de 0,95). 
Os fatores correspondentes à atividade de água, temperatura, tipo de substrato, presença ou ausência de microflora competitiva, linhagem do fungo e danos nos grãos, influenciam a produção de ocratoxina A (Marquardt \& Frohlich, 1992 e Moss, 1996).

O desenvolvimento e a produção de ocratoxina A das espécies $A$. alutaceus e $P$. verrucosum diferem nas condições de atividade de água $\mathrm{e}$ temperatura. $\mathrm{O}$ desenvolvimento do $A$. alutaceus ocorre com atividade de água mínima de $0,76 \mathrm{e}$ do $P$. verrucosum com atividade de água mínima de 0,81 . A atividade de água mínima e ótima para produção de ocratoxina $\mathrm{A}$, tanto para o $A$. alutaceus quanto para o $P$. verrucosum, é de 0,85 e acima de 0,97, respectivamente (Moss, 1996). Todavia, Marquardt \& Frohlich (1992), relatam que a atividade mínima e ótima de água para ambas espécies pode variar de 0,83 a 0,90 e 0,95 a 0,99 , em grãos armazenados à temperatura de $24^{\circ} \mathrm{C}$. Para o $A$. alutaceus, o intervalo de temperatura, no qual é possível a síntese de ocratoxina, e a temperatura ótima de produção da toxina, com atividade de água ótima, é de 12 a $37^{\circ} \mathrm{C} \mathrm{e}$ $25^{\circ} \mathrm{C}$ e para o $P$. verrucosum é de 4 a $31^{\circ} \mathrm{C}$ e $24^{\circ} \mathrm{C}$, respectivamente (Moss, 1996).

Ressalta-se que o $P$. verrucosum contamina, com maior freqüência, os cereais de regiões de clima temperado e o A. alutaceus ocorre com maior intensidade em regiões de clima tropical e subtropical (Marquardt \& Frohlich, 1992).

$\mathrm{O} A$. alutaceus produz menos ocratoxina $\mathrm{A}$ em grãos de milho e trigo em relação a grãos de soja e amendo im, ocorrendo o inverso com $P$. verrucosum (Madhyastha et al., 1990).

A presença de microflora não produtora de ocratoxina $\mathrm{A}$, em grãos de cevada, suprime a biossíntese de Ocratoxina A por A. alutaceus (Marquardt \& Frohlich, 1992).

A germinação de esporos de $P$. verrucosum em grãos de cevada não foi afetada pela presença de $A$. flavus ou de $F$. sporotrichioides; contudo, a infecção dos grãos foi fortemente inibida por $A$. flavus e levemente inibida por $F$. sporotrichioides, na maioria das condições testadas. A presença de um ou de outro fungo, na maioria das condições testadas, pouco inibiu a colonização dos grãos por $P$. verrucosum. Todavia, a produção de ocratoxina por $P$. verrucosum foi inibida, no geral, e às vezes significativamente, quando na presença de $A$. flavus. Sua síntese não foi acentuadamente afetada pela presença de $F$. sporotrichioides, verificando-se em alguns momentos, o aumento 
temporário da Ocratoxina A durante o período de incubação (Ramakrishna et al., 1996b).

Isolou-se, em ordem decrescente de freqüência, Fusarium spp, Penicillium spp e Aspergillus spp, em avaliações mensais de amostras de milho coletadas em Ribeirão Preto, SP, o qual permaneceu armazenado durante um ano, em sacos de $60 \mathrm{~kg}$, com umidade entre 12,3 e 17,8\%, e em condições de umidade relativa do ar entre 64 e 97,5\%, temperatura média do ar mínima de $18,4^{\circ} \mathrm{C}$ e máxima de $24,1^{\circ} \mathrm{C}$ e chuva próximo a 337 milímetros. O Penicillium spp predominou em amostras com umidade entre 12,3 e $13,6 \%$, não havendo correlação significativa entre a população do fungo e os fatores abióticos. Todavia, não foi detectada a presença de ocratoxina A (Pozzi et al. 1995).

\subsubsection{Destoxificação}

A ocratoxina A é urma molécula de moderada estabilidade, a qual resistirá à maioria dos processos das indústrias de alimentação em alguma extensão (Scott, 1996).

A meia vida da toxina, em trigo seco a $100,150,200$ e $250^{\circ} \mathrm{C}$ foi calculada em 707, 201, 12 e 6 minutos, respectivamente, enquanto que em trigo úmido a 100, 150 e $200^{\circ} \mathrm{C}$ chegou-se a 145, 60 e 19 minutos, respectivamente, indicando menor termo-estabilidade da molécula na presença de água (Moss, 1996). Tais resultados contrariam aqueles obtidos por Trenk et al. (1971) que verificaram maior estabildade ao autoclavar torta de aveia e arroz com $50 \%$ de água.

Scott (1984), conseguiu até $20 \%$ de redução nos teores de ocratoxina A com processos que utilizam calor (fervura, cozimento, pasteurização e panificação), enquanto que na torrefação a temperaturas de 200 a $250^{\circ} \mathrm{C}$, ocorreu redução de 32 a $80 \%$.

A autoclavagem a $132^{\circ} \mathrm{C}$, durante 0,5 hora, não alterou o valor nutritivo da cevada e reduziu-lhe o nível de contaminação em $75 \%$. Este processo foi considerado ineficaz e impraticável (Madsen et al., 1983), apesar de outros autores conseguirem redução de até $100 \%$ de ocratoxina com a referida técnica (Chelkowski et al. 1981 e 1982). 
Marquardt \& Frohlich (1992), revisando trabalhos de diversos autores relatam que o ratamento com $1 \%$ de HSCAS e 1 a $10 \%$ de bentonita não evitou os efetos tóxicos de ocratoxina presente na dieta de suínos. O tratamento com $1 \%$ de carvão ativado, na dieta de suínos, causou pequeno decréscimo na concentração de ocratoxina A e com $10 \%$ de carvão ativado reduziu em 50 a $80 \%$, podendo esta concentração ser utilizada na terapia e não na profilaxia de suínos, a qual é imprópria para galinhas. A colestiramina, resina de troca aniônica, parece agir como absorvente efetivo no trato gastrointestinal de animais não ruminantes, no entanto, apresenta custo elevado. $O$ uso de fenilalanina na suplementação de dietas contaminadas com Ocratoxia A parece proteger as galinhas contra as toxicoses, porém reduz-lhes o ganho de peso e a conversão alimentar. A suplementação com proteínas em dietas contaminadas com ocratoxina A, diminuiu os efeitos tóxicos, melhorou o desenvolvimento e reduziu a mortalidade de galinhas, apesar da acentuada relação custo-beneficio.

Com relação ao processo de limpeza, este não eliminou a ocratoxina $\mathrm{A}$ em trigo e cevada (Scott, 1984), enquanto que, de acordo com Scott (1996), no processo de moagem úmida de milho ficou $51 \%$ da ocratoxina nas frações amido, fibra e glúten.

A amoniação de cevada contaminada com ocratoxina $\mathrm{A}$, utilizando-se $0,5 \%$ de $\mathrm{NH}_{3}$ durante $96 \mathrm{~h} \mathrm{a} 70^{\circ} \mathrm{C}$, e o aquecimento de grãos a $150^{\circ} \mathrm{C}$ na presença de $\mathrm{NaOH}$, não alterou o valor nutritivo da cevada e reduziu-lhe o nível de contaminação em $\mathbf{7 5 \%}$. Porém, Madsen et al., (1983), consideram esses processos ineficazes e impraticáveis, apesar de outros autores conseguirem redução de até $100 \%$ de ocratoxina com as referidas técnicas (Chelkowski et al. 1981 e 1982).

A maior parte da ocratoxina A encontra-se no interior dos grãos de trigo e cevada e somente 10 a $50 \%$ da toxina pode ser extraída e removida da superfície com clorofórmio (Subirade, 1996).

O processo de ensilagem de cevada naturalmente cortaminada reduziu consideravelmente os teores de ocratoxina A, contudo, a toxicidade permaneceu nos testes com galinhas (Scott, 1996).

O processo de fermentação, na cervejaria, reduziu a ocratoxina A entre 72 e $98 \%$ (Scott, 1984), porém, a inoculação com Lactobacillus na ensilagem de cevada 
naturalmente comtaminada com ocratoxina $\mathrm{A}$, reduziu a concentração em aproximadamente $50 \%$. No entanto, aparentemente, as enzimas da bactéria não foram capazes de hidrolisar com eficiência a ligação amida da toxina e, consequentemente, reduzir a toxicidade à aves (Rotter et al., 1990).

Os níveis de ocratoxina $\mathrm{A}$ encontrados na ração destinada a alimentação de animais são mais altos que os detectados na carne e nos seus derivados, sendo o processamento da carne de pouca ou nenhuma influência sobre os níveis da micotoxina (Subirade, 1996).

\subsection{Micotoxinas de Fusarium}

\subsubsection{Fungos toxigênicos de maior importância}

O gênero Fusarium metabolisa zearalenona e os tricotecenos toxina T-2 e desoxinivalenol. Nijs et al. (1996), revisando trabalhos de vários autores, realizados no período de 1969 até o início de 1995, relatam que vinte e cinco espécies de Fusarium, isoladas em produtos e subprodutos naturais de milho, biossintetisam micotoxinas em condições controladas de laboratório. Entre estas espécies, o $F$. moniliforme está relacionado à produção de zearalenona, toxina $\mathrm{T}-2$ e fumonisinas $\mathrm{B}_{1}, \mathrm{~B}_{2}, \mathrm{~B}_{3}, \mathrm{~B}_{4}$ e $\mathrm{C}_{1}, \mathrm{o}$ $F$. graminearum relacionado à zearalenona, toxina T-2 e desoxinivalenol (DON ou vomitoxina), o $F$. sporotrichioides à toxina $\mathrm{T}-2$, o $F$. poae à toxina $\mathrm{T}-2$ e desoxinivalenol, o $F$. oxysporum à zearalenona e toxina T-2 e o $F$. culmorum e o $F$. crookwellense à zearalenona, toxina T-2 e desoxinivalenol. 


\subsubsection{Micotoxicoses}

\subsubsection{Zearalenona}

De acordo com Diekman \& Green (1992) o Fusarium spp produz micotoxinas não estrogênicas, desoxinivalenol, nivalenol, toxina T-2. e diacetoxiscirpenol, e estrogênicas, incluindo zearalenona e zearalenol.

A zearalenona causa hiperestrogenismo em suínos (Diekman \& Green, 1992), sendo estes mais sensíveis que bovinos, aves e animais de laboratório, comparativamente (Coulombe, 1993), o qual pode ser reversível em suínos. Ainda, a zearalenona produz efeitos de pseudo prenhez, infertilidade, alteração no ciclo do cio, natimortos, "splay leg" em leitões durante a gestação e aborto em matrizes, bem como atrofia de ovários em suínos em lactação (Diekman \& Green, 1992).

Os efeitos são bem menores nos bovinos, contudo pode levar à infertilidade e à queda de produção de leite (Miller, 1995), enquanto que, Lazzari (1997) cita que em aves a toxina causa muito pouco hiperestrogenismo.

A zearalenona causa efeitos também no Homem, estando associada à mudança de idade em que crianças atingem a puberdade e, adicionalmente, a IARC considera a toxina com potencial carcinogênico para a espécie humana (Miller, 1995).

\subsubsection{Toxina $T-2$}

Lazzari (1995) cita que a micotoxina interfere no sistema nervoso, imunológico e digestivo de aves, bovinos e suínos, sendo característico dos tricotecenos os sintomas de imunossupressão, hemorragia no trato gastrointestinal, êmese, recusa alimentar (Marasas et al., 1984) e ataxia, resultante da inibição da síntese de proteínas (Smith, 1992). 


\subsubsection{Desoxinivalenol}

O desoxinivalenol provoca recusa de ingestão alimentar e ocasionalmente vômito, afetando a performance dos animais (Diekman \& Green, 1992). De acocordo com as citações de Lazzari (1997), causa enterite e diarréia, diminui a fertilidade de matrizes, aumenta a mortalidade de leitões na fase de amamentação e compromete o sistema imunológico de suínos.

As aves são mais tolerantes à toxina em relação aos suínos, podendo sofrer redução na qualidade de ovos e no ganho de peso. Os bovinos toleram bem a micotoxina, no entanto, tem-se observado casos de redução na ingestão alimentar e na natalidade (Miller, 1995).

\subsubsection{Condições favoráveis para a biossíntese}

\subsubsection{Zearalenona}

A zearalenona pode ser sintetizada, em milho, em ambiente com temperaturas constantes ou alternadas e com alta umidade. A síntese da toxina pelo $F$. graminearum ocorre em substratos com umidade entre 25 e $65 \%$ (ótima de $45 \%$ ) e em condições ambientais de temperaturas alternadas entre 22 e $27^{\circ} \mathrm{C}$ alternada com 5 a $35^{\circ} \mathrm{C}$, com ótimo de produção entre 22 a $27^{\circ} \mathrm{C}$ alternada ccom 12 a $15^{\circ} \mathrm{C}$. O desenvolvimento de $F$. graminearum e a produção de zearalenona, em milho, foi verificado a partir de $7^{\circ} \mathrm{C} \mathrm{com}$ $24 \%$ de umidade, a partir de 12 e $18^{\circ} \mathrm{C}$ com $16 \%$ de umidade em ambas e a partir de $25^{\circ} \mathrm{C}$ com $14 \%$ de umidade, cuja umidade e temperatura ótimas foi de $40 \%$ e $25^{\circ} \mathrm{C}$, alternado com $14^{\circ} \mathrm{C}$. Ainda, a atividade de água ótima verificada para esta espécie, em milho, foi acima de 0,97 . As temperaturas médias máxima de $26^{\circ} \mathrm{C}$ e mínima de $16^{\circ} \mathrm{C}$ são consideradas ótimas para infestação de grãos de milho por $F$. graminearum em condições de campo.

De 42 isolados de F. graminearum, forma imperfeita da Gibberella zeae, provenientes de espigas de milho armazenadas na região de Minnesota e sul de Dakota, 
EUA, sete deles produziram entre 100.000 e $1.900 .000 \mathrm{ng} / \mathrm{g}$ de zearalenona. $\mathrm{O}$ isolado $\mathrm{n}^{\circ} 1$, o qual sintetizou o máximo de zearalenona $(1.900 .000 \mathrm{ng} / \mathrm{g}$ ), produziu 3.087 .000 $\mathrm{ng} / \mathrm{g}$ em arroz parboilizado polido, $2.585 .000 \mathrm{ng} / \mathrm{g}$ em milho, 2.845.000 ng/g em trigo, $1.053 .000 \mathrm{ng} / \mathrm{g}$ em arroz em casca, $363.000 \mathrm{ng} / \mathrm{g}$ em aveia, $993.000 \mathrm{ng} / \mathrm{g}$ em cevada, não sendo detectada em soja e ervilha, quando incubado durante duas semanas a $24-27^{\circ} \mathrm{C}$ seguido de 8 semanas a $12^{\circ} \mathrm{C}$. Esse mesmo isolado, em substrato de milho, produziu zearalenona quando incubado durante 8 semanas entre 5 e $35^{\circ} \mathrm{C}$, após 2 semanas a $22-25^{\circ} \mathrm{C}$, atingindo o máximo a $15^{\circ} \mathrm{C}$. Quando incubado durante 2 semanas a $22-25^{\circ} \mathrm{C}$ seguido de 8 semanas a $12^{\circ} \mathrm{C}$, produziu zearalenona com umidade do milho entre 25 e $65 \%$, cujo pique de síntese foi obtido em $45 \%$. Ainda, ao ser incubado por 2 semanas a $24-27^{\circ} \mathrm{C}$, seguido de 1 a 12 semanas a $12^{\circ} \mathrm{C}$ e $25^{\circ} \mathrm{C}$; atingiu o máximo de produção de zearalenona após 10 semanas a $12^{\circ} \mathrm{C}$, em torno de $4.000 .000 \mathrm{ng} / \mathrm{g}$, e após 8 semanas a $25^{\circ} \mathrm{C}$, em torno de $1.000 .000 \mathrm{ng} / \mathrm{g}$ de peso seco do substrato (Eugenio et. al, 1970).

Sherwood \& Peberdy (1974), observaram que o desenvolvimento de $F$. graminearum, bem como a produção de zearalenona em milho, ocorre em condições combinadas de temperatura e umidade a partir de $7^{\circ} \mathrm{C}, 24 \% ; 12$ a $18^{\circ} \mathrm{C}, 16 \%$ e $25^{\circ} \mathrm{C}$, 14\%. Ressalta-se que as avaliações foram realizadas com temperaturas de 7, 12, $18 \mathrm{e}$ $25^{\circ} \mathrm{C}$ e umidade do substrato, base seca, entre 14 e $37 \%$, sendo que a máxima produção de zearalenona ocorreu nas temperaturas de 12 e $18^{\circ} \mathrm{C}$, para umidade de grãos entre $18 \mathrm{e}$ $37 \%$. Por outro lado, Greenhalgh et al. (1983), obteve a maior produção de zearalenona por $F$. graminearum em milho incubado a $28^{\circ} \mathrm{C}$ durante 28 dias.

Ainda, Martins (1994) testou a produção de zearalenona por F. graminearum em substratos de milho moído, trigo moído e trinca de arroz, com umidade ajustada para 30, 35,40 e $45 \%$, em temperatura constante de $25^{\circ} \mathrm{C}$ durante 3,5 e 7 semanas e em temperatura de $25^{\circ} \mathrm{C}$ durante uma semana seguido de 2,4 e 6 semanas a $14^{\circ} \mathrm{C}$. O autor concluiu que houve produção de zearalenona em todas as situações; no entanto, os teores mais elevados foram determinados no milho, com $40 \%$ de umidade alternado-se 1 semana a $25^{\circ} \mathrm{C}$ seguida de 4 semanas a $14^{\circ} \mathrm{C}$.

De acordo com Siame \& Lovelace (1994), em Zâmbia, na África, o milho, freqüentemente, apresenta-se com alta infestação de $F$. graminearum no campo, quando 
as condições de temperatura situam-se entre a média máxima de $26^{\circ} \mathrm{C}$ e a mínima de $16^{\circ} \mathrm{C}$. Adicionalmente, a produção de zearalenona é favorecida por temperatura entre 12 e $16^{\circ} \mathrm{C}$. Ainda, segundo os mesmos autores, a produção de zearalenona foi de 5.000 a $1.300 .000 \mathrm{ng} / \mathrm{g}$ em milho moído e inoculado com $F$. graminearum, quando incubado à temperatura constante de $16^{\circ} \mathrm{C}$ e, entre 5.000 a $250.000 \mathrm{ng} / \mathrm{g}$ à $26^{\circ} \mathrm{C}$ durante 10 semanas.

Bilgrami et al. (1995), trabalhando com a linhagem de $F$. graminearum BUML 294 em substrato de arroz polido com umidade de 25, 35 e 50\%, temperaturas constantes de 12 e $25^{\circ} \mathrm{C}$, durante 3 e 6 semanas, em temperaturas diurnas de $27^{\circ} \mathrm{C}$ alternada com temperaturas noturnas de $16^{\circ} \mathrm{C}$, durante 3 e 6 semanas, e com temperaturas de $25^{\circ} \mathrm{C}$ durante 1,5 e 3 semanas seguidas de $12^{\circ} \mathrm{C}$ durante 1,5 e 3 semanas, observaram produção de zearalenona em todas as situações e constataram também que houve incremento da referida toxina em função do aumento da umidade, sendo que as maiores produções ocorreram na temperatura de $25^{\circ} \mathrm{C}$, seguida de $12^{\circ} \mathrm{C}$.

Jiménez et al. (1996) testaram as linhagens G1, G2 e G3 de $F$. graminearum, as linhagens $\mathrm{C} 1$ e $\mathrm{C} 2$ de $F$. culmorum e as linhagens $\mathrm{O} 1$ e $\mathrm{O} 2$ de $F$. oxysporum, isoladas em milho, para produção de zearalenona, quando incubadas à temperatura ambiente $\left(16-25^{\circ} \mathrm{C}\right)$ e a $28^{\circ} \mathrm{C}$ durante duas semanas seguido de $12^{\circ} \mathrm{C}$ e $37^{\circ} \mathrm{C}$ constante, durante 10 , 20, 30 e 40 dias, com atividade de água 0,97 e 0,95. Os autores concluíram que nenhuma linhagem produziu zearalenona nos níveis detectáveis a $37^{\circ} \mathrm{C}$. A linhagem $\mathrm{G} 3$ produziu os níveis mais altos de zearalenona em todos os ambientes atingindo 600.000, 1.200.000, $4.250 .000,5.900 .000$ e $6.200 .000 \mathrm{ng} / \mathrm{g}$ aos $10,15,20,30$ e 40 dias respectivamente a $16-25^{\circ} \mathrm{C}$ e $7.100 .000 \mathrm{ng} / \mathrm{g}$ aos 40 dias a $28 / 12^{\circ} \mathrm{C}$ com atividade de água 0,97 e 2.700 , 8.500 e $9.300 \mathrm{ng} / \mathrm{g}$ aos 20,30 e 40 dias a $16-25^{\circ} \mathrm{C}$ com atividade da água de 0,95 . As linhagens G1, O1 e O2 não produziram zearalenona com atividade de água de 0,95, enquanto que o $F$. culmorum iniciou a produção da toxina somente a partir de 30 dias. Ainda, a linhagem G2 produziu zearalenona a partir de 15 dias, enquanto G1, C1, C2, $\mathrm{O} 1$ e $\mathrm{O} 2$ a partir de 20 dias em temperatura de $16-25^{\circ} \mathrm{C}$ e atividade de água de 0,97 .

Pozzi et al. (1995), constataram correlação significativa e positiva entre a população de Fusarium spp e a umidade de grãos, bem como, correlação negativa com os fatores umidade relativa do ar de 64 a 97,5\%, temperatura mínima média do ar de 
$18,4^{\circ} \mathrm{C}$, temperatura máxima média de $24,1^{\circ} \mathrm{C}$, chuva próximo a $337 \mathrm{~mm}$, e tempo de armazenamento, em avaliação realizada em grãos de milho armazenados durante um ano, em Ribeirão Preto, São Paulo, em sacos de 60 kg, com umidade entre 12,3 e 17,8\%. Ressalta-se que os autores não detectaram zearalenona, e que as duas espécies predominantes de Fusarium, em ordem decrescente, foram $F$. moniliforme e $F$. proliferatum.

A ocorrência simultânea de zearalenona e desoxinivalenol pode ser considerado fato comum (Scott, 1989 citado por Miller, 1995), sendo a coexistência de ambas detectada em espigas de milho naturalmente contaminadas com F. graminearum por Grabarkiewicz-Szczesna et al. (1996).

\subsubsection{Toxina $T-2$}

A biossintese da micotoxina é possível em ambientes com temperaturas constantes entre 8 e $25^{\circ} \mathrm{C}$, com umidade alta (atividade de água acima 0,95) ou em ambientes com temperatura de $25-27^{\circ} \mathrm{C}$ alternadas com 12 a $16^{\circ} \mathrm{C}$. A presença de $A$. flavus ou de $P$. verrucosum no ambiente, pode afetar a infecção e a colonização de grãos, sem interferir na germinação dos esporos, bem como resultar no estímulo à produção da toxina T-2.

A condição ótima para biossíntese da toxina T-2 é 8 a $10^{\circ} \mathrm{C}$ com atividade de água próximo a 1,0 (Marasas et al., 1984). Quando ocorre mudança nas condições de temperatura, variando de $20^{\circ} \mathrm{C}$ para $30^{\circ} \mathrm{C}$, esta micotoxina modifica-se em toxina HT-2 (Kotsonis \& Ellison, 1975, citados por Ramakrishna et al., 1996a).

Bilgrami et al. (1995), observaram produção da toxina T-2 ao trabalhar com F. sporotrichioides BUML 110 em substrato de arroz polido, com umidade de $25,35 \mathrm{e}$ $50 \%$; em temperaturas constantes de 12 e $25^{\circ} \mathrm{C}$ durante 3 e 6 semanas; em temperatura diurna de $27^{\circ} \mathrm{C}$ alternada com temperatura noturna de $16^{\circ} \mathrm{C}$ durante 3 e 6 semanas e em temperatura de $25^{\circ} \mathrm{C}$ durante 1,5 e 3,0 semanas seguida de $12^{\circ} \mathrm{C}$ durante 1,5 e 3,0 semanas. Ficou evidente o incremento em função do aumento da umidade, sendo que as maiores produções ocorreram na temperatura constante de $25^{\circ} \mathrm{C}$. 
A germinação dos esporos de $F$. sporotrichioides não foi afetada, quando incubado durante 3 semanas em grãos de cevada com atividade de água 0,97 e 0,95-0,90 a $20^{\circ} \mathrm{C}$ e $30^{\circ} \mathrm{C}$, na presença de $A$. flavus ou de $P$. verrucosum. Contudo, a subsequente infecção dos grãos e a colonização foi afetada em maior ou menor extensão pela presença dos fungos. A produção de toxina $\mathrm{T}-2$ ocorreu somente a $20^{\circ} \mathrm{C}$ com atividade de água de 0,97 e 0,95, sendo, em geral, maior quando os referidos fungos estavam presentes (Ramakrishna et al., 1996a).

A severidade de infecção por Fusarium e da contaminação por tricotecenos aumenta com o tempo seco na colheita e com o armazenamento em condições de umidade relativa alta (Desjardins et al., 1993).

\subsubsection{Desoxinivalenol}

O desoxinivalenol pode ser biossintetisado em ambientes com temperaturas constantes entre 12 e $28^{\circ} \mathrm{C}$ (ótima de 25 a $28^{\circ} \mathrm{C}$ ), em substratos com umidade entre 22 a $50 \%$ (ótimo de 50\%), não sendo verificada a produção do metabólito em grãos com 13 a $14 \%$ de umidade. A síntese também pode ocorrer em ambientes com temperaturas de $25-27^{\circ} \mathrm{C}$ alternadas com $12-16^{\circ} \mathrm{C}$. Ainda, é possível ocorrer a síntese simultânea de desoxinivalenol e zearalenona em substrato de milho submetido a temperaturas constantes entre 16 e $26^{\circ} \mathrm{C}$ ou $26^{\circ} \mathrm{C}$ alternada com $16^{\circ} \mathrm{C}$.

A infecção por $F$. graminearum requer períodos com temperatura ótima de 24 a $26^{\circ} \mathrm{C}$, moderadas chuvas, principalmente durante o período de maior receptividade dos estilo-estigmas até o estádio inicial de desenvolvimento dos grãos de milho (Koehler, 1959; Tuite et al., 1974 e Sutton, 1982), enquanto a temperatura ótima para produção de desoxinivalenol é de 25 a $28^{\circ} \mathrm{C}$ (Siame \& Lovelace, 1994). Ainda, esses autores observaram, em Zâmbia, na África, milho com alta infestação de $F$. graminearum quando o clima apresentava-se com temperatura média máxima de $26^{\circ} \mathrm{C}$ e a mínima de $16^{\circ} \mathrm{C}$.

O amazenamento de grãos com umidade entre 13 e $14 \%$ previne o desenvolvimento de $F$. graminearum, bem a produção de desoxinivalenol e zearalenona, 
enquanto que, em grãos armazenados com 22 a $23 \%$ de urnidade, o fungo produz altas concentrações dessas micotoxinas. Ressalta-se também que o desoxinivalenol e a zearalenona, geralmente, estão presentes em milho infectado por $F$. graminearum (Diekman \& Green, 1992).

A produção simultânea de zearalenona foi, aproximadamente, cinco vezes maior que desoxinivalenol em milho moído e inoculado com $F$. graminearum, quando incubado à temperatura constante de $26^{\circ} \mathrm{C}$ e vinte e seis vezes a $16^{\circ} \mathrm{C}$ durante 10 semanas. A produção de desoxinivalenol foi levemente maior em temperatura constante de $26^{\circ} \mathrm{C}(1.000$ a $62.000 \mathrm{ng} / \mathrm{g})$ em relação a $16^{\circ} \mathrm{C}(1.000$ a $50.000 \mathrm{ng} / \mathrm{g})$. Quando incubado durante as primeiras 5 semanas a $26^{\circ} \mathrm{C}$ seguido de 5 semanas a $16^{\circ} \mathrm{C}$, a produção simultânea das toxinas para desoxinivalenol foi de 1.000 a $45.000 \mathrm{ng} / \mathrm{g}$ e para zearalenona entre 1.000 a $250.000 \mathrm{ng} / \mathrm{g}$. Ainda, quando incubado em condições semelhantes, a $16^{\circ} \mathrm{C}$ seguido de $26^{\circ} \mathrm{C}$, os níveis de desoxinivalenol ficaram entre $1.000 \mathrm{e}$ $137.000 \mathrm{ng} / \mathrm{g}$ e, de zearalenona entre 1.000 e $750.000 \mathrm{ng} / \mathrm{g}$. Ressalta-se que os menores valores foram obtidos na segunda semana a partir do início da incubação (Siame \& Lovelace, 1994).

A produção de desoxinivalenol foi observada por Bilgrami et al. (1995), em $F$. graminearum BUML 102, incubado em substrato de arroz polido com umidade de 25 , 35 e 50\%; em temperaturas constantes de 12 e $25^{\circ} \mathrm{C}$, durante 3 e 6 semanas; em temperaturas diumas de $27^{\circ} \mathrm{C}$ alternada com temperaturas noturnas de $16^{\circ} \mathrm{C}$, durante $3 \mathrm{e}$ 6 semanas, e em temperaturas de $25^{\circ} \mathrm{C}$ durante 1,5 e 3 semanas, seguidas de $12^{\circ} \mathrm{C}$ durante 1,5 e 3 semanas. Os autores verificaram também incremento da síntese da micotoxina com o acréscimo de umidade, sendo que as maiores produções ocorreram nas temperaturas constantes de $25^{\circ} \mathrm{C}$ e nas temperaturas alternadas de $25^{\circ} \mathrm{C}$, durante 1,5 e 3 semanas, seguido de $12^{\circ} \mathrm{C}$ por 1,5 e 3 semanas.

Verificou-se correlação significativa e positiva entre a população de Fusarium spp e a umidade de grãos de milho armazenados em sacos de $60 \mathrm{~kg}$, com umidade entre 12,3 e 17,8\%, durante um ano, em Ribeirão Preto, São Paulo. Ainda, nessa avaliação, os autores encontraram correlação negativa entre a população de Fusarium spp e a umidade relativa do ar de 64 a $97,5 \%$, temperatura média do ar mínima de $18,4^{\circ} \mathrm{C}$, temperatura 
máxima de $24,1^{\circ} \mathrm{C}$, chuva próximo a $337 \mathrm{~mm}$ e o tempo de armazenamento. Nesse mesmo trabalho, não foi detectado desoxinivalenol, ressaltando-se que as duas espécies predominantes de Fusarium isoladas, em ordem decrescente, foram $F$. moniliforme e $F$. proliferatum (Pozzi et al., 1995).

\subsubsection{Destoxificação}

\subsubsection{Zearalenona}

Poucos trabalhos referentes à destoxificação de zearalenona estão disponíveis na literatura.

A toxina citada não é solúvel em água e o ponto de fusão é de $164-165^{\circ} \mathrm{C}$ (Cole $\&$ Cox, 1981). Ainda, a maioria dos processos que utilizam fermentação e calor parecem apresentar baixa eficiência na destoxificação.

De acordo com Scott (1984) a panificação reduziu os teores iniciais de zearalenona entre 30 a $40 \%$ e ainda o processo de destilação não arrastou zearalenona nos produtos alcóolicos de milho, remanescendo no bagaço, aproximadamente, o dobro da concentração inicial. Sibanda et al. (1997) relatam que a zearalenona foi detectada em cerveja fabricada com sorgo, em Lesotho, na África, e concluíram que pequena porção da toxina é degradada durante a fermentação.

No processo de moagem úmida de milho naturalmente contaminado, a zearalenona concentra-se, em ordem decrescente, nas frações solúveis, glúten, fibra e gérmen, as quais normalmente são destinadas para ração animal, não sendo detectada, ao limite de 50 a $100 \mathrm{ng} / \mathrm{g}$, na fração amido, a qual perfaz entre 65 a $71 \%$ do total do grão (Bennett \& Richard, 1996).

Ainda, de acordo com os mesmos autores, no processo de moagem seca de milho naturalmente contaminado, a limpeza seca de grãos não reduziu a contaminação dos lotes, pois todas as frações da moagem permaneceram contaminadas, sendo que os níveis mais altos foram detectados nas cascas e nas frações gordurosas. 
Os agentes de hidrólise podem atingir um nível alto de destoxificação, porém a praticidade e o custo para grandes volumes de milho podem não ser adequados por necessitar uma fonte de energia. De acordo com Ramos \& Hernãndez (1991) o milho tratado com $2 \%$ de hidróxido de cálcio a $100^{\circ} \mathrm{C}$ reduziu entre 59 e $100 \%$ o teor de zearalenona.

Os adsorventes de troca aniônica parecem adsorver melhor a zearalenona, apesar de haver a necessidade de maiores estudos para a sua utilização (Ramos et al. 1996).

\subsubsection{Toxina $\mathrm{T}-2$}

Os tricotecenos não foram intensamente estudados quanto à destoxificação, sendo os processos que envolvem o calor e o processamento de milho para consumo humano de baixa viabilidade técnica.

Os tricotecenos são estáveis a temperaturas de $120^{\circ} \mathrm{C}$ e moderadamente estáveis a $180^{\circ} \mathrm{C}$, decompondo-se a $200-210^{\circ} \mathrm{C}$, durante 30 a 40 minutos de exposição (Ramos \& Hernãndez, 1991). O ponto de fusão da toxina T-2 é de $151-152^{\circ} \mathrm{C}$ (Cole \& Cox, 1981), apesar de se mostrar mais estável quando submetida aos processos que utilizam calor, em relação à aflatoxina, zearalenona e ocratoxina A (Scott, 1984).

De acordo com Bennett \& Richard (1996), os tricotecenos desoxinivalenol e a toxina T-2, não são destruídos durante o processamento usado para o preparo de produtos de milho para consumo humano.

A toxina T-2 mostrou-se mais solúvel que aflatoxina e zearalenona, na moagem úmida de milho, distribuindo-se em $67 \%$ na porção aquosa, $4 \%$ no amido e o restante entre o gérmen, glúten e a porção fibrosa (Scott, 1984).

O processo de destilação de etanol e a diluição de grãos contaminados com grãos sadios são os poucos métodos efetivos e econômicos de destoxificação de grãos contaminados com tricotecenos (Desjardins et al., 1993). 


\subsubsection{Desoxinivalenol}

Poucas são as informações encontradas na literatura referentes à destoxificação de desoxinivalenol. Os processos que utilizam calor, os agentes de oxidação (bisulfito de sódio), os agentes de hidrólise (amônia e hidróxido de cálcio), sozinhos ou combinados, apresentam-se em geral com baixa eficiência. A moagem úmida ou seca concentra a toxina em alguns subprodutos, sejam eles destinados à alimentação humana ou animal. A separação de grãos de milho, com aparência anormal, daqueles considerados sadios, através do processo de classificação, provavelmente não atingirá $100 \%$ de redução da toxina, tendo em vista a detecção desta em grãos sadios.

O desoxinivalenol é estável no processo de panificação, enquanto a aflatoxina e a zearalenona são de estabilidade intermediária (Scott, 1984). Quando se utiliza farinha tratada com bisulfito de sódio, o teor da toxina aumenta 50 a $75 \%$ em relação ao nível inicial, indicando que a degradação não é estável (Ramos \& Hernãndez, 1991).

Ainda, de acordo com Ramos \& Hernãndez (1991), o tratamento de milho com $2 \%$ de hidróxido de cálcio a $100^{\circ} \mathrm{C}$ reduziu o teor de desoxinivalenol entre 72 e $82 \%$ e, quando tratado com bisulfito de sódio, seguido de autoclavagem, o desoxinivalenol foi degradado em 90 a $95 \%$ do teor inicial.

Em estudos realizados em moinho comercial que processa o milho a seco, o desoxinivalenol foi encontrado em concentrações mais elevadas na farinha de gérmen destinada a alimentação animal. Nos moinhos que utilizam o processo de moagem úmida, a toxina concentrou-se na fase aquosa e no amido, enquanto que a menor porção de aflatoxina $B_{1}$, zearalenona e toxina $T-2$ foram encontradas nestas frações (Scott, 1984).

O tratamento de alimentos com amônia à temperatura ambiente e pressão ambiente necessita uma exposição de duas a três semanas e quando submetido a temperaturas entre 80 a $120^{\circ} \mathrm{C}$ e pressão de 20 a $40 \mathrm{lb} / \mathrm{pol}^{2}$ o tempo reduz-se a menos de uma hora, necessitando de umidade acima de 10-20\% e concentrações de amônia superiores a 5\%, sendo observado um potencial de degradação do desoxinivalenol de 85\% (Ramos \& Hemãndez, 1991). 
O desoxinivalenol foi encontrado em concentrações maiores no sabugo, seguido de grãos apresentando sintomas e grãos sem sintomas de infecção de $F$. graminearum DAOM 194276, inoculado em cinco híbridos de milho, em experimento conduzido no campo. O fungo foi isolado em 5 a 32\% dos grãos sem sintomas visíveis (Reid et al., 1996). Contudo, Grabarkiewicz-Szczesna et al. (1996) detectaram desoxinivalenol nas frações de grãos danificados por $F$. graminearum e em sabugos e palhas de espigas naturalmente infectadas por $F$. graminearum, o mesmo não ocorrendo para a fração grãos sadios.

\subsection{Ocorrência de micotoxinas em milho, no Brasil}

Os trabalhos de pesquisa relativos a ocorrência de micotoxinas em milho, originado de diversas regiões do Brasil, concentraram-se na segurança alimentar, avaliando o nível de contaminação em pós-colheita e subprodutos, à exceção de um trabalho, o qual investigou o nível de contaminação natural de aflatoxinas a partir do estádio de 25 dias após a polinização do milho, em Campinas, estado de São Paulo.

Das 2.267 amostras analisadas para aflatoxinas, 796 estavam positivas $(35,1 \%)$, cujo nível máximo de contaminação foi de $1.097 \mathrm{ng} / \mathrm{g}$ (Prado, 1983; Scussel et al., 1986; Sabino et al., 1986; Fiorentin et al., 1989; Prado et al., 1992; Prado et al., 1995; Gloria, 1995 e Hennigen \& Dick, 1995).

Scussel et al. (1986) não detectaram aflatoxinas em amostras de milho de quatro cultivares coletadas 25,40 e 70 dias após a polinização, no município de Campinas, estado de São Paulo.

Fonseca et al. (1982 e 1983), Sabino et al. (1986), Prado et al. (1992), Prado et al. (1995), Hennigen \& Dick (1995), Gloria (1995) e Santurio et al. (1996) analisaram 1.892 amostras e detectaram ocratoxina $\mathrm{A}$ em apenas 4 amostras $(0,2 \%)$, cujo valor máximo foi de $744,8 \mathrm{ng} / \mathrm{g}$.

Das 2.188 amostras analisadas para zearalenona, $70(3,2 \%)$ apresentaram-se positivas para a toxina, cujo valor máximo detectado foi de $9.830 \mathrm{ng} / \mathrm{g}$ (Fonseca et 
al.,1982 e 1983; Sabino et al., 1986; Sabino et al., 1989; Prado et al., 1992; Prado et al. 1995; Gloria, 1995; Santurio et al., 1996 e Hennigen \& Dick, 1995).

Prado et al. (1997) analisaram 88 amostras de milho para a toxina T-2, ao limite de detecção de $50 \mathrm{ng} / \mathrm{g}$, procedentes dos estados do Paraná e Goiás, e encontraram apenas uma delas $(1,1 \%)$ contaminada com $104 \mathrm{ng} / \mathrm{g}$. Ainda, desse total de amostras, cinco (5,7\%) estavam positivas para desoxinivalenol, ao nível de deteç̧ão de $90 \mathrm{ng} / \mathrm{g}$, cujo valor máximo encontrado foi de $542 \mathrm{ng} / \mathrm{g}$.

\subsection{Prevenção de micotoxinas no campo: aspectos gerais}

A síntese de micotoxinas pode ocorrer ainda no campo, antes da colheita, não havendo processos, isolados, eficientes de caracter técnico e econômico para descontaminação do produto. Quando a síntese das micotoxinas não ocorre até a fase de colheita, o manejo dos produtos é facilitado, favorecendo medidas preventivas para evitar a contaminação a partir da referida fase.

As aflatoxinas podem ser sintetizadas ainda no campo, antes da colheita (Payne, 1992), a partir de duas semanas após a floração do milho (Anderson et al., 1975) e durante o armazenamento, sendo de fácil manejo no armazém quando prevenida em condições de campo (Payne, 1992).

Nos Estados Unidos da América, os sistemas de armazenamento permitem o controle eficiente na prevenção de aflatoxinas, sendo a maior preocupação correspondente às medidas de manejo da cultura para evitar a contaminação do milho até a fase de colheita (Miller, 1995).

O armazenamento de grãos de milho com 13\% de umidade, em ambiente com $15^{\circ} \mathrm{C}$ e $61 \%$ de umidade relativa mostrou-se seguro para evitar a produção de aflatoxina por $A$. flarus, contrariando as recomendações da FAO de $27^{\circ} \mathrm{C}, 13,5 \%$ de umidade de grão e 70\% de umidade relativa (Asevedo et al., 1993).

A ocratoxina A é mais comumente encontrada na fase de pós-colheita, podendo ocorrer em pré colheita e durante a colheita (Battalglia et al., 1996). Grãos colhidos no 
campo, isentos da toxina, podem ser preservados da contaminação, quando armazenados com umidade abaixo de $15 \%$ (Marquardt \& Frohlich, 1992).

As micotoxinas de Fusarium spp., zearalenona e desoxinivalenol são produzidas com maior freqüência no campo, até a fase de colheita, enquanto a toxina T-2, é produzida por $F$. sporotrichioides, quando os grãos permanecem na lavoura em condições de alta umidade (Miller, 1995).

Não se conhece o estádio sexual do A. flavus (Payne, 1992), cujos conídios são produzidos no início do florescimento do milho e disseminados através do ar e insetos até os estilo-estigmas das plantas, local a partir do qual o fungo penetra na espiga. Ainda, pode sobreviver nos restos culturais de milho, na forma de micélio, e no solo sob a forma de esclerócio, cuja estrutura pode permanecer viável por muitos anos (Miller, 1995), bem como na forma de conídios (Payne, 1992), o que lhe confere baixa vulnerabilidade de controle baseado em programas de rotações de culturas curtas (Reis \& Forcelini, 1995).

Após quatro décadas de pesquisa em aflatoxinas na cultura de milho, ainda não se conhece medidas isoladas e consistentes para seu controle, incluindo o melhoramento de plantas objetivando a busca de genótipos comerciais resistentes a essa toxina (Miller, 1995).

O F. graminearum e o $F$. moniliforme são necrotróficos, com baixa especificidade de hospedeiros e com fase saprofitica vulnerável por não ter evidências da sobrevivência no solo, em estruturas de resistência, nas condições brasileiras. Contudo, não enquadram-se como fungos totalmente controláveis por rotação de culturas, devido a disseminação do inóculo, através do vento e da chuva (Reis \& Casa, 1996 e Reis \& Forcelini, 1995).

As micotoxinas de $F$. graminearum, desoxinivalenol e zearalenona, podem ser eliminadas através do melhoramento de plantas, todavia, acredita-se que levará de uma a duas décadas para disponibilizar genótipos comerciais (Miller, 1995).

De acordo com o mesmo autor, o impacto das práticas agronômicas sobre as doenças de $F$. graminearum, em condições de epidemias, tem sido modesto, incluindo o uso de fungicidas, o qual pode resultar em maior acúmulo de micotoxinas nas cutturas, através de intervenções no metabolismo dos fungos. 


\section{MATERIAIS E MÉTODOS}

\subsection{Delineamento experimental, coleta e preparo das amostras}

O presente trabalho foi conduzido em lavouras comerciais de milho, situadas a

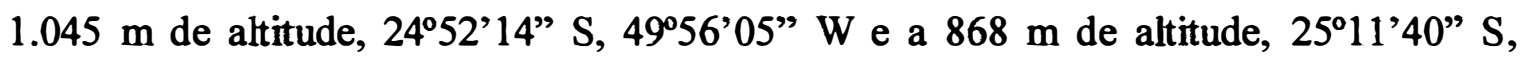
5052'29" W, nos municípios de Arapoti e Castro, respectivamente, na região dos Campos Gerais do Paraná, estado do Paraná, Brasil, no ano agrícola de 1997/98. Nessa região, de acordo com o sistema de classificação internacional de Koeppen (1931), o clima é do tipo Cfa (clima temperado, quente e úmido, sem estiagem).

O genótipo avaliado foi o Dinamilho 766, previamente testado para tolerância às diferentes micotoxinas (Molin, 1997 - dados não publicados), o qual foi semeado em Arapoti, no dia 12/09/97 e em Castro, no dia 03/10/97, e conduzido sob o sistema de plantio direto com a tecnologia adotada naquelas regiões, objetivando a obtenção de rendimento de grãos entre 8,0 e 9,0 toneladas por hectare.

Os tratamentos foram compostos por intervalos de coleta de amostras de dez dias, a partir do estádio fenológico $8 / 9$ (início da colheita de milho para ensilagem de plantas inteiras), os quais foram dispostos em delineamento experimental de blocos ao acaso com nove repetições, conforme apresentado nas Tabelas 1 e 2.

Tabela 1. Tratamentos estudados.

\begin{tabular}{ll}
\hline Tratamentos & \multicolumn{1}{c}{ Descrição dos tratamentos } \\
\hline 1 & Estádio fenológico 8/9 (grãos para ensilagem de plantas inteiras) \\
2 & Final do estádio fenológico 9 (grãos para ensilagem de plantas inteiras) \\
3 & Estádio fenológico 10 (ensilagem de grãos úmidos) \\
4 & 10 dias após o estádio fenológico 10 \\
5 & 20 dias após o estádio fenológico 10 \\
\hline Obs: O intervalo de coleta das amostras foi de 10 dias para todos os tratamentos.
\end{tabular}


Tabela 2. Escala de desenvolvimento de milho proposta por Hanway (1966) e Nel \& Smit (1978), adaptada por Fancelli (1996).

\begin{tabular}{ll}
\hline Estádio fenológico & \multicolumn{1}{c}{ Descrição } \\
\hline 0 & Da semeadura à emergência \\
1 & Planta com quatro folhas totalmente desdobradas \\
2 & Planta com oito folhas totalmente desdobradas \\
3 & Planta com doze folhas totalmente desdobradas \\
4 & Emissão do pendão \\
5 & Florescimento e polinização \\
6 & Grãos leitosos \\
7 & Grãos pastosos \\
8 & Início da formação de "dentes" \\
9 & Grãos "duros" \\
10 & Grãos maturos fisiologicamente \\
\hline
\end{tabular}

As unidades experimentais foram compostas de duas linhas espaçadas em 0,8 metros, previamente demarcadas em uma gleba isolada de $50 \mathrm{~m}$ de largura por 100 metros de comprimento, de maneira que a massa de grãos das espigas, com $13 \%$ de umidade (base úmida), resultasse em amostra contendo um mínimo de 3,0 kg. Ressaltase que foram incluídas 15 plantas com presença de espigas em cada linha componente da unidade experimental.

A colheita, o despalhamento e a tritha de espigas foram realizadas manualmente, para evitar a contaminação de amostras e danos mecânicos de grãos. As amostras, devidamente identificadas, foram acondicionadas em sacos de algodão higienizados e encaminhadas para o laboratório de rotina LACEN, pertencente à Batávia S.A., localizado no município de Carambeí, PR, até 10 horas após a coleta.

As amostras foram pesadas antes e após a secagem em estufa com circulação de ar, regulada à temperatura de $65^{\circ} \mathrm{C}$, durante 72 horas, acondicionadas dentro de frascos perfurados com capacidade de $500 \mathrm{ml}$. Posteriormente, procedeu-se a moagem grosseira utilizando-se peneira com furos redondos de 4,5 a $4,9 \mathrm{~mm}$ de diâmetro e a homogeneização das amostras, seguido da padronização para $0,5 \mathrm{~kg}$, com o uso de um quarteador, objetivando a geração de amostras de trabalho e contra-amostras. A seguir, realizou-se a moagem fina (peneira de malha 20 "mesh"), a homogeneização e a composição das amostras de trabalho e das contra-amostras. Cada amostra de trabalho 
foi novamente homogeneizada antes da composição da amostra analítica, com tamanho de 50 gramas, no momento das determinações laboratoriais das micotoxinas aflatoxinas $\left(B_{1}, B_{2}, G_{1}\right.$ e $\left.G_{2}\right)$, ocratoxina $A$, zearalenona, toxina $T-2$ e desoxinivalenol. Cumpre ressaltar que todas amostras foram armazenadas em ambiente à $-0,4^{\circ} \mathrm{C}$, até o momento da análise.

\subsection{Metodologia analítica}

\subsubsection{Placas cromatográficas e padrões}

Utilizou-se cromatofolhas com dimensões de $10 \mathrm{~cm}$ x $10 \mathrm{~cm}$ e espessura da camada de sílica gel de $0,25 \mathrm{~mm}$, para cromatografia em camada delgada.

As aflatoxinas $B_{1}, B_{2}, G_{1}$ e $G_{2}$, ocratoxina $A$, zearalenona, toxina $T-2$ e desoxinivalenol foram adquiridas da empresa Sigma Chemical Co, na forma cristalina.

As soluções padrão de trabalho foram preparadas na concentração de $0,5 \mu \mathrm{g}$ de aflatoxina $B_{1}$ e $G_{1}$ e $0,15 \mu \mathrm{g}$ de aflatoxina $B_{2}$ e $G_{2} / \mathrm{ml}$ de clorofôrmio, $50 \mu \mathrm{g}$ de zearalenona $/ \mathrm{ml}$ de etanol, $1 \mu \mathrm{g}$ de ocratoxina $\mathrm{A} / \mathrm{ml}$ de benzeno, $25 \mu \mathrm{g}$ de toxina $\mathrm{T}-2 / \mathrm{ml}$ de acetonitrilo e $20 \mu \mathrm{g}$ de desoxinivalenol $/ \mathrm{ml}$ de acetonitrilo.

O controle do processo analítico, através do teste de recuperação de micotoxinas, foi realizado valendo-se de amostras de milho, com níveis não detectáveis das toxinas em questão, a cada 14 amostras analisadas, perfazendo um total de 7 amostras para o grupo aflatoxinas, ocratoxina e zearalenona e 7 amostras para o grupo toxina T-2 e desoxinivalenol. Para tal, as amostras de 50 gramas foram contaminadas ao nível de 10 $\mathrm{ng} / \mathrm{g}$ de aflatoxina $\mathrm{B}_{1}, 20 \mathrm{ng} / \mathrm{g}$ de ocratoxina $\mathrm{A}, 1.000 \mathrm{ng} / \mathrm{g}$ de zearalenona, $500 \mathrm{ng} / \mathrm{g}$ de toxina T-2 e $400 \mathrm{ng} / \mathrm{g}$ de desoxinivalenol. Os valores de recuperação obtidos e os coeficientes de variação encontram-se na Tabela 3. 
Tabela 3. Valores de recuperação e coeficientes de variação obtidos no controle do processo analítico, após a adição de micotoxinas em amostras de milho.

\begin{tabular}{|c|c|c|c|c|c|c|}
\hline \multirow[t]{2}{*}{ Micotoxina } & \multicolumn{4}{|c|}{ Valor (ng/g) } & \multirow{2}{*}{$\begin{array}{l}\text { Coeficiente de } \\
\text { Variação (\%) }\end{array}$} & \multirow{2}{*}{$\begin{array}{c}\text { Recuperação } \\
(\%)^{1}\end{array}$} \\
\hline & Teórico & prático & mínimo & máximo & & \\
\hline Aflatoxina $B_{1}$ & 10,0 & 9,8 & 9,0 & 11,0 & $\overline{7,1}$ & 98,0 \\
\hline Ocratoxina A & 20,0 & 17,0 & 14,0 & 19,0 & 9,3 & 85,0 \\
\hline Zearalenona & $1.000,0$ & $1.046,0$ & 996,0 & $1.102,0$ & 3,9 & 105,0 \\
\hline Toxina $T-2$ & 500,0 & 451,0 & 400,0 & 490,0 & 7,9 & 90,0 \\
\hline Desoxinivalenol & 400,0 & 345,0 & 304,0 & 397,0 & 9,8 & 86,0 \\
\hline
\end{tabular}

\subsubsection{Extração das micotoxinas e clarificação dos extratos}

\subsubsection{Aflatoxinas $B_{1}, B_{2}, G_{1}$ e $G_{2}$, Ocratoxina $A$ e zearalenona}

A extração das aflatoxinas $B_{1}, B_{2}, G_{1}$ e $G_{2}$, ocratoxina $A$ e zearalenona e a clarificação dos extratos foram realizados simultaneamente, de acordo com a metodologia desenvolvida por Soares \& Rodriguez-Amaya (1989), com pequenas adaptações, conforme fluxograma apresentado a seguir:

50 gramas de amostra

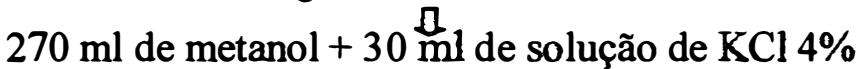
agitação em agitador orbital mecânico durante 30 minutos

$$
1^{\text {a. }} \text { filtragem }
$$

$150 \mathrm{ml}$ do filtrado $+150 \mathrm{ml}$ de solução de $\mathrm{NH}_{4} \mathrm{SO}_{2} 30 \%$

$$
2^{\text {a. }} \text { filtragem }
$$

$150 \mathrm{ml}$ do filtrado $+150 \mathrm{ml}$ de $\mathrm{H}_{2} \mathrm{O}$ deionizada em funil de separação

extração com $20 \mathrm{ml}$ de clorofồrmio (6 minutos de agitação em agitador orbital mecânico seguido de repouso de 3 a 4 minutos)

coleta de $10 \mathrm{ml}$ da solução de clorofôrmio

lavagem com aproximadamente $30 \mathrm{ml}$ de clorofôrmio em filtro com sulfato de sódio anidro

$$
\text { a }
$$

concentração do extrato em evaporador rotativo em banho maria a $40^{\circ} \mathrm{C}$ transferência do extrato (lavagem com clorofôrmio) para frasco marrom âmbar

Evaporação até a secura sob fluxo de nitrogênio e armazenagem a $-15^{\circ} \mathrm{C}$ 


\subsubsection{Toxina T-2 e desoxinivalenol}

A extração de toxina T-2 e desoxinivalenol, bem como a clarificação dos extratos foram realizadas simultaneamente, de acordo com a metodologia proposta por Romer (1986), modificada, conforme fluxograma abaixo:

0 gramas de amostra

extração (90 ml de acetonitrilo + $10 \mathrm{ml}$ de solução de $\mathrm{KCl} 4 \%$ )

agitação em agitador orbital mecânico durante 30 minutos

$1^{\text {a. }}$ filfyagem

clarificação e filtragem ( $10 \mathrm{ml}$ do filtrado em coluna com carvão ativado, óxido de alumínio e celite sob vácuo)

lavagem e filtragem ( $10 \mathrm{ml}$ de acetonitrilo + solução de $\mathrm{KCL} 4 \%, 9: 1$, em coluna

composta de carvão ativado, óxido de alumínio e celite sob vácuo)

secagem do extrato em banho maria a $95^{\circ} \mathrm{C}$, conjugado com fluxo de nitrogênio

adição de $2 \mathrm{ml}$ de solução de acetona + metanol, 2:1 + agitação em agitador orbital mecânico durante 20 minutos

transferência do extrato para tubo de ensaio, secagem em banho maria a $60^{\circ} \mathrm{C} \mathrm{e}$

armazenagem $\mathrm{a}-15^{\circ} \mathrm{C}$

Os extratos permaneceram armazenados a $-15^{\circ} \mathrm{C}$ durante um período máximo de duas horas.

\subsubsection{Triagem de micotoxinas}

\subsubsection{Aflatoxinas $B_{1}, B_{2}, G_{1}$ e $G_{2}$, ocratoxina $A$ e zearalenona}

Nessa etapa, adicionou-se $500 \mu \mathrm{l}$ de benzeno no conteúdo extraído das amostras, que estava acondicionado em frasco âmbar de volume aproximado de $20 \mathrm{ml}$. A seguir, a solução da amostra foi agitada durante 30 segundos em agitador Vortex Biomatic. 
A triagem foi realizada através da técnica de cromatografia em camada delgada, em duas direções, para minimizar a formação do "cometa" amarelo e facilitar a visualização das micotoxinas.

Foram aplicados $2 \mu \mathrm{l}, 1 \mu \mathrm{l}$ e $2 \mu \mathrm{l}$ das soluções padrão de zearalenona, aflatoxinas e ocratoxina, respectivamente nas posições 1,2 e 3 da cromatofolha. Na posição 4 , foi aplicado $10 \mu \mathrm{l}$ da solução do extrato da amostra, após a agitação. Nas posições 5, 7 e 10 foram aplicados, respectivamente, $0,5 \mu \mathrm{l}, 1,0 \mu \mathrm{l}$ e $2,0 \mu \mathrm{l}$ da solução padrão de zearalenona. Nas posições 6 e 9 foram aplicados, respectivamente, 1,0 $\mu$ e 3,0 $\mu \mathrm{l}$ da solução padrão de aflatoxinas e nas posições 8 e 11 aplicou-se 1,0 $\mu$ l e 3,0 $\mu$ l da solução padrão de ocratoxina $\mathrm{A}$. As posições da cromatofolha mencionadas encontram-se ilustradas na Figura 1.

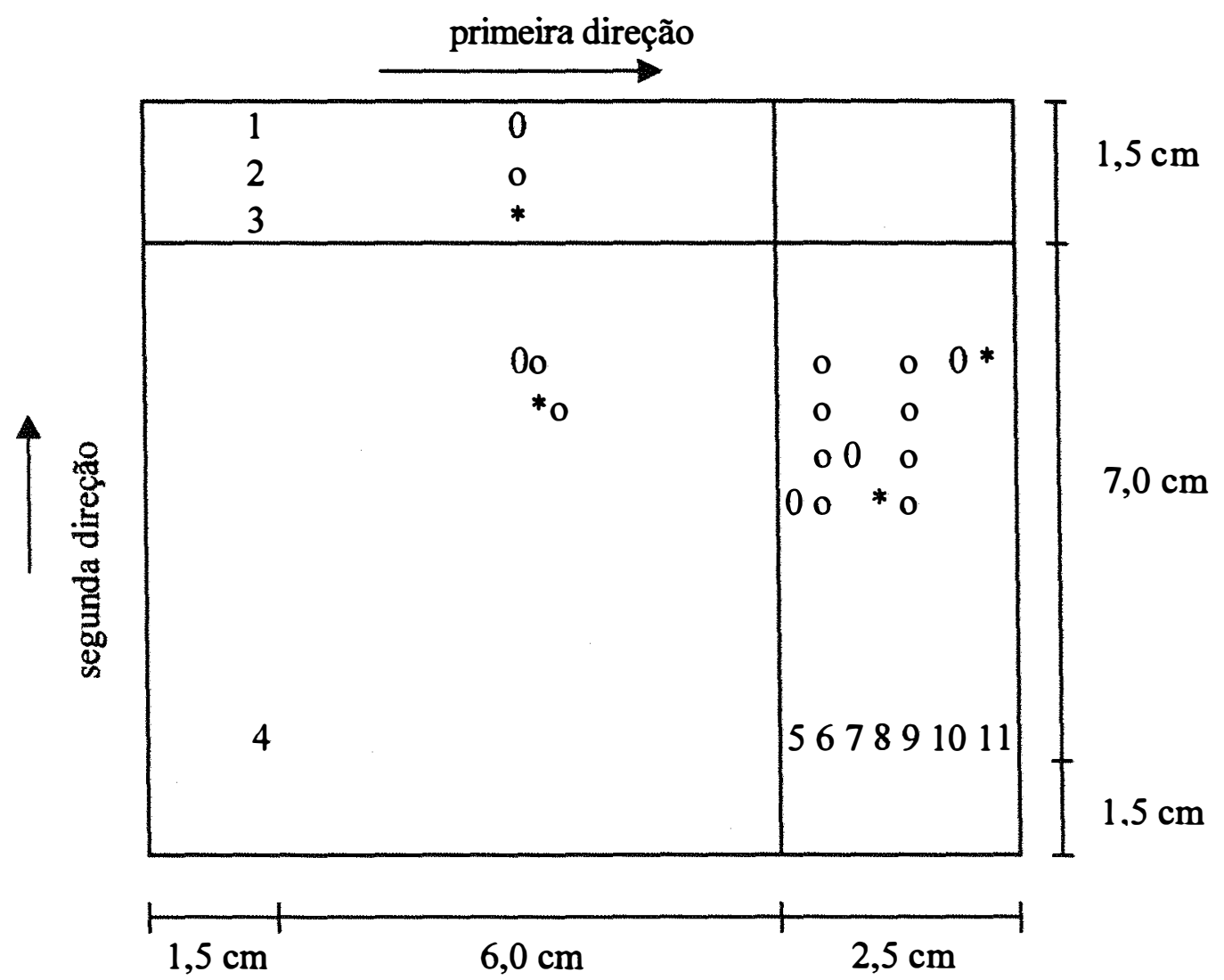

Figura 1. Ilustração da cromatofolha com as posições de aplicação das soluções padrão $(1,2,3,5,6,7,8,9,10$ e 11$)$, solução da amostra (4), primeira e segunda direção da fase móvel e pontos fluorescentes $\left(0,0 \mathrm{e}^{*}\right)$. 
Ainda, sempre que foi detectado indício da presença de micotoxinas, repetiu-se o procedimento acima descrito, utilizando-se diferentes cromatofolhas para cada grupo de toxinas analisadas.

A aplicação das soluções padrões e da solução da amostra na cromatofolha foram realizadas com microseringa, sob fluxo de nitrogênio, para volatilização dos solventes.

A técnica de separação bidirecional permitiu um limite de visualização de $1 \mathrm{ng} / \mathrm{g}$ para as aflatoxinas analisadas, $4 \mathrm{ng} / \mathrm{g}$ para ocratoxina A e $100 \mathrm{ng} / \mathrm{g}$ para zearalenona.

De acordo com a concentração das micotoxinas nas soluções das amostras, quando necessário, alíquotas das soluções padrão e/ou, da solução das amostras, diferentes das descritas, foram aplicadas em novas cromatofolhas, para viabilizar a comparação das fluorescências.

O desenvolvimento da fase móvel na primeira direção, para aflatoxinas, zearalenona e ocratoxina, foi em $50 \mathrm{ml}$ de solução de clorofórmio e acetona na proporção de 9:1, durante 10 minutos. Após a secagem da cromatofolha, desenvolveu-se a fase móvel na segunda direção em $50 \mathrm{ml}$ de solução de tolueno, acetato de etila e ácido fórmico $88 \%$, 5:4:1, durante 10 minutos. O sentido da fase móvel encontra-se ilustrado na Figura 1.

Após a nova secagem da cromatofolha, esta foi submetida à luz ultravioleta de ondas longas (366 nm) para visualização das aflatoxinas e ocratoxina A e, de ondas curtas (254 nm) para visualização de zearalenona.

As manchas fluorescentes, com tonalidade e posição concordantes com as soluções padrão, foram consideradas pressupostamente positivas para a micotoxina específica.

\subsubsection{Toxina T-2 e desoxinivalenol}

Para essa avaliação, adicionou-se $200 \mu$ l de solução de acetona e metanol, 2:1, no conteúdo extraído das amostras que estava acondicionado em tubos de ensaio com capacidade aproximada de $5 \mathrm{ml}$. A seguir, a solução da amostra foi agitada durante 30 segundos em agitador Vortex Biomatic. 
A triagem foi realizada em duas direções e em cromatofolhas distintas para cada micotoxina.

Ainda, foram aplicados $1 \mu$ de solução padrão de desoxinivalenol ou da toxina T-2 na posição 1 e $5 \mu$ da solução da amostra na posição 4, após a agitação. Também, aplicou-se $0,5 \mu \mathrm{l}, 1,0 \mu \mathrm{l}$ e 2,0 $\mu \mathrm{l}$ de solução padrão de desoxinivalenol nas posições 5, 7 e 9 da cromatofolha, respectivamente. O padrão da toxina T-2, em volumes de $1 \mu \mathrm{l} \mathrm{e}$ $3 \mu$, foi aplicado nas posições 5 e 7, respectivamente, conforme ilustradas na Figura 1.

A aplicação das soluções padrão e da solução da amostra na cromatofolha foram realizadas com microseringa e sob fluxo de nitrogênio para volatilizar os solventes.

A metodologia de separação bidirecional empregada, permitiu um limite de visualização de $80 \mathrm{ng} / \mathrm{g}$ para desoxinivalenol e $100 \mathrm{ng} / \mathrm{g}$ para a toxina T-2.

De acordo com a concentração das micotoxinas nas soluções das amostras, quando necessário, alíquotas das soluções padrão e/ou, da solução das amostras, diferentes das descritas, foram aplicadas em novas cromatofolhas, para viabilizar a comparação das fluorescências.

A fase móvel na primeira direção, para desoxinivalenol, foi desenvolvida em $50 \mathrm{ml}$ de solução de clorofórmio, acetona e álcool isopropílico, 8:1:1, durante 10 minutos. Procedimento semelhante foi realizado para a toxina $\mathrm{T}-2$, porém em clorofórmio e metanol, 9,7:0,3.

Após a secagem das cromatofolhas, desenvolveu-se a fase móvel das toxinas mencionadas na segunda direção, em $50 \mathrm{ml}$ de solução de tolueno, acetato de etila e ácido fórmico $88 \%$, 5:4:1, durante 10 minutos.

A seguir, as cromatofolhas para análise de desoxinivalenol foram pulverizadas com solução de cloreto de alumínio 20\% (200 g de cloreto de alumínio $+500 \mathrm{ml} \mathrm{de}$ etanol $+500 \mathrm{ml}$ de água deionizada), para tornar a toxina fluorescente, e deixadas em estufa de ar forçado a $130^{\circ} \mathrm{C}$, durante 5 minutos, para secagem. As cromatofolhas destinadas à determinação de toxina $\mathrm{T}-2$ foram pulverizadas com solução de ácido sulfúrico e metanol, 2:8, e secadas em estufa de ar forçado à temperatura de $130^{\circ} \mathrm{C}$ durante 2 minutos. 
As cromatofolhas foram submetidas à luz ultravioleta de ondas longas (366 nm) para visualização de desoxinivalenol e toxina T-2.

As manchas fluorescentes, com tonalidades e posições concordantes com as soluções padrões, foram consideradas pressupostamente positivas para a micotoxina específica.

\subsubsection{Quantificação de micotoxinas}

Após a submissão da cromatofolha à luz ultravioleta e a comparação da tonalidade e posição com a solução padrão, foi efetuado o cálculo da concentração de micotoxinas aplicando-se a seguinte expressão matemática:

Concentração de micotoxinas $(\mathrm{ng} / \mathrm{g})=\frac{\mathrm{S} \times \mathrm{Y} \times \mathrm{V}}{\mathrm{X} \times \mathrm{W}}$

onde:

$\mathrm{S}=\mu \mathrm{l}$ da solução padrão de trabalho correspondente à solução da amostra.

$\mathrm{Y}=$ concentração do padrão de trabalho, em $\mu \mathrm{g} / \mathrm{ml}$.

$\mathrm{V}=$ volume final, em $\mu \mathrm{l}$, da solução da amostra (500 $\mu \mathrm{l}$ para aflatoxinas, ocratoxina A e zearalenona e $200 \mu \mathrm{l}$ para toxina T-2 e desoxinivalenol).

$\mathrm{X}=$ volume aplicado da solução da amostra, em $\mu \mathrm{l}$.

$\mathrm{W}=$ peso da amostra, em gramas, na solução da amostra $(6,25 \mathrm{~g}$ para aflatoxinas, ocratoxina A e zearalenona e 5,00 g para toxina $\mathrm{T}-2$ e desoxinivalenol).

\subsubsection{Confirmação}

A confirmação das amostras pressupostamente positivas, para as micotoxinas específicas, foi realizada através da técnica de co-cromatografia.

Assim, uma cromatofolha adicional foi utilizada para cada amostra positiva, na qual aplicou-se $10 \mu \mathrm{l}$ da solução de amostra positiva para aflatoxinas ou zearalenona ou 
ocratoxina A ou $5 \mu$ l da solução de amostra positiva para desoxinivalenol ou toxina T-2 a ser confirmada, na posição 4 da placa, conforme esquematizada na Figura 1. Juntamente com a alíquota da solução da amostra, foi aplicado determinada quantidade do padrão da micotoxina a ser confimada, de maneira que a mesma produzisse fluorescência de intensidade levemente superior à toxina em questão. A mesma alíquota do padrão foi aplicada também nas posições 1 e 5 .

Após o desenvolvimento da fase móvel nos sistemas de solventes anteriormente mencionados, comparou-se as características da mancha suspeita com a correspondente da placa, na qual o padrão não foi aplicado junto com a amostra A mancha continuou sendo considerada positiva, quando as posições eram coincidentes e com tonalidade de fluorescência característica.

\subsection{Análise estatística}

Os dados obtidos não seguem a distribuição normal, mesmo quando transformados, bem como não se enquadram em outros modelos padrões de análise, sendo portanto, apresentada uma análise descritiva dos mesmos. Ressalta-se também, que este procedimento de análise é comumente utilizado para trabalhos desta natureza. 


\section{RESULTADOS}

A população final de plantas de milho obtida, foi de 67,4 e 59,9 mil plantas ha, a qual ficou além do esperado, e o rendimento médio de grãos obtido nos ensaios foi de 10.094 e $8.999 \mathrm{~kg} / \mathrm{ha} \mathrm{em} \mathrm{Arapoti} \mathrm{e} \mathrm{Castro,} \mathrm{respectivamente.}$

O tamanho mínimo e máximo das amostras de grãos obtidos nas trinta plantas com presença de espigas, nas noventa unidades experimentais, foi de $3,084 \mathrm{~kg}$ e $5,735 \mathrm{~kg}$, respectivamente, com $13 \%$ de umidade, base úmida.

Nas amostras coletadas na região de Arapoti, PR, não foi detectado aflatoxinas ao nível de $1 \mathrm{ng} / \mathrm{g}$, conforme constatado na Tabela 4. Por outro lado, a referida toxina foi detectada em apenas duas das 45 amostras coletadas em Castro, PR, em níveis entre 1 e $2 \mathrm{ng} / \mathrm{g}$, ou seja, uma relativa ao tratamento $4(11,1 \%)$ e outra pertencente ao tratamento 5 (11,1\%), conforme Tabela 5.

Tabela 4. Níveis de aflatoxinas, por classe e por tratamento, determinadas nas 45 amostras coletadas em Arapoti, PR, em 1998.

\begin{tabular}{lccccr}
\hline Classe (ng/g) & \multicolumn{5}{c}{ \% de amostras positivas para aflatoxinas, por tratamento } \\
\cline { 2 - 6 } & 1 & 2 & 3 & 4 & 5 \\
\hline$<1$ & $100(9)$ & $100(9)$ & $100(9)$ & $100(9)$ & $100(9)$ \\
\hline Total & $100(9)$ & $100(9)$ & $100(9)$ & $100(9)$ & $100(9)$ \\
\hline
\end{tabular}

Os valores entre parênteses indicam o número de amostras analisadas correspondentes ao percentual. Nível de detecção $=1 \mathrm{ng} / \mathrm{g}$. Tratamento 1 = estádio fenológico 8/9, início da fase de grãos para ensilagem de plantas inteiras, tratamento 2 = final do estádio fenológico 9, fase de grãos para ensilagem de plantas inteiras, tratamento $3=$ estádio fenológico 10 , fase de ensilagem de grãos úmidos, tratamento $4=10$ dias após o estádio fenológico 10, tratamento $5=20$ dias após o estádio fenológico 10. Todas amostras foram coletadas em intervalos de 10 dias. 
Tabela 5. Níveis de aflatoxinas, por classe e por tratamento, determinadas nas 45 amostras coletadas em Castro, PR, em 1998.

\begin{tabular}{lccccr}
\hline Classe (ng/g) & \multicolumn{5}{c}{ \% de amostras positivas para aflatoxinas, por tratamento } \\
\cline { 2 - 6 } & 1 & 2 & 3 & 4 & 5 \\
\hline$<1$ & $100(9)$ & $100(9)$ & $100(9)$ & $88,9(8)$ & $88,9(8)$ \\
1 a 2 & - & - & - & $11,1(1)$ & $11,1(1)$ \\
\hline Total & $100(9)$ & $100(9)$ & $100(9)$ & $100(9)$ & $100(9)$ \\
\hline
\end{tabular}

Os valores entre parênteses indicam o número de amostras analisadas correspondentes ao percentual. Nível de deteç̧ão $=1 \mathrm{ng} / \mathrm{g}$. Tratamento $\mathrm{l}=$ estádio fenológico $8 / 9$, início da fase de grãos para ensilagem de plantas inteiras, tratamento 2 = final do estádio fenológico 9, fase de grãos para ensilagem de plantas inteiras, tratamento $3=$ estádio fenológico 10 , fase de ensilagem de grãos úmidos, tratamento $4=10$ dias após o estádio fenológico 10 , tratamento $5=20$ dias após o estádio fenológico 10 . Todas amostras foram coletadas em intervalos de 10 dias.

A biossíntese de zearalenona foi a mais intensa entre as toxinas analisadas nos dois locais. A mencionada micotoxina foi detectada em 11,1\% das amostras coletadas em Arapoti no tratamento 2 (801 e $900 \mathrm{ng} / \mathrm{g}$ ); em 44,4\% das amostras no tratamento 3 $(11,1 \%$ entre 100 e $200 \mathrm{ng} / \mathrm{g}-22,2 \%$ entre 301 e $400 \mathrm{ng} / \mathrm{g}-11,1 \%$ entre 401 e $500 \mathrm{ng} / \mathrm{g})$; em 44,4\% das amostras do tratamento 4 (11,1\% entre 301 e $400 \mathrm{ng} / \mathrm{g}-22,2 \%$ entre 401 e $500 \mathrm{ng} / \mathrm{g}-11,1 \%$ entre 701 e $800 \mathrm{ng} / \mathrm{g})$ e em $22,2 \%$ das amostras do tratamento $5(11,1 \%$ com níveis entre 401 a 500 ng/g e 11,1\% entre 601 a $700 \mathrm{ng} / \mathrm{g}$ ), não sendo detectada apenas no tratamento 1 (Tabela 6). Nas amostras coletadas em Castro, a zearalenona foi detectada em freqüências e intensidades de contaminação maiores em relação à Arapoti, principalmente nos tratamentos 3 e 5 . A referida toxina estava positiva em $66,6 \%$ das amostras do tratamento 3 (33,3\% com níveis de contaminação entre 201 e 300 ng/g$11,1 \%$ entre 401 e $500 \mathrm{ng} / \mathrm{g}-11,1 \%$ entre 501 e $600 \mathrm{ng} / \mathrm{g}-11,1 \%$ entre 901 e $1.000 \mathrm{ng} / \mathrm{g}$ ); em 44,4\% das amostras do tratamento 4 (33,3\% entre 100 e $200 \mathrm{ng} / \mathrm{g}$ e $11,1 \%$ entre 301 e $400 \mathrm{ng} / \mathrm{g})$ e em $88,9 \%$ das amostras do tratamento $5(22,2 \%$ entre 201 e $300 \mathrm{ng} / \mathrm{g}-1,1 \%$ entre 301 e $400 \mathrm{ng} / \mathrm{g}-11,1 \%$ entre 401 e $500 \mathrm{ng} / \mathrm{g}-11,1 \%$ entre 501 e $600 \mathrm{ng} / \mathrm{g}-11,1 \%$ entre 801 e $900 \mathrm{ng} / \mathrm{g}-11,1 \%$ entre 1.601 e $1.700 \mathrm{ng} / \mathrm{g}-11,1 \%$ entre 1.701 e $1.800 \mathrm{ng} / \mathrm{g}$ ), não sendo detectada nos tratamentos 1 e 2 conforme mostra a Tabela 7. 
Tabela 6. Níveis de zearalenona, por classe e por tratamento, determinados nas 45 amostras coletadas em Arapoti, PR, em 1998.

\begin{tabular}{lccccc}
\hline Classe (ng/g) & \multicolumn{5}{c}{$\%$ de amostras positivas para zearalenona, por tratamento } \\
\cline { 2 - 6 } & 1 & 2 & 3 & 4 & 5 \\
\hline$<100$ & $100(9)$ & $88,9(8)$ & $55,6(5)$ & $55,6(5)$ & $77,8(7)$ \\
100 a 200 & - & - & $11,1(1)$ & - & - \\
301 a 400 & - & - & $22,2(2)$ & $11,1(1)$ & - \\
401 a 500 & - & - & $11,1(1)$ & $22,2(2)$ & $11,1(1)$ \\
601 a 700 & - & - & - & - & $11,1(1)$ \\
701 a 800 & - & - & - & $11,1(1)$ & - \\
801 a 900 & - & $11,1(1)$ & - & - & - \\
\hline Total & $100(9)$ & $100(9)$ & $100(9)$ & $100(9)$ & $100(9)$ \\
\hline
\end{tabular}

Os valores entre parênteses indicam o número de amostras analisadas correspondentes ao percentual. Nível de detecção $=100 \mathrm{ng} / \mathrm{g}$. Tratamento $1=$ estádio fenológico $8 / 9$, início da fase de grãos para ensilagem de plantas inteiras, tratamento 2 = final do estádio fenológico 9, fase de grãos para ensilagem de plantas inteiras, tratamento $3=$ estádio fenológico 10 , fase de ensilagem de grãos úmidos, tratamento $4=$ 10 dias após o estádio fenológico 10 , tratamento $5=20$ dias após o estádio fenológico 10 . Todas amostras foram coletadas em intervalos de 10 dias.

Tabela 7. Níveis de zearalenona, por classe e por tratamento, determinados nas 45 amostras coletadas em Castro, PR, em 1998.

\begin{tabular}{lccccc}
\hline Classe (ng/g) & \multicolumn{5}{c}{$\%$ de amostras positivas para zearalenona, por tratamento } \\
\cline { 2 - 6 } & 1 & 2 & 3 & 4 & 5 \\
\hline$<100$ & $100,0(9)$ & $100,0(9)$ & $33,3(3)$ & $55,6(5)$ & $11,1(1)$ \\
100 a 200 & - & - & - & $33,3(3)$ & - \\
201 a 300 & - & - & $33,3(3)$ & - & $22,2(2)$ \\
301 a 400 & - & - & - & $11,1(1)$ & $11,1(1)$ \\
401 a 500 & - & - & $11,1(1)$ & - & $11,1(1)$ \\
501 a 600 & - & - & $11,1(1)$ & - & $11,1(1)$ \\
801 a 900 & - & - & - & - & $11,1(1)$ \\
901 a 1000 & - & - & $11,1(1)$ & - & - \\
1601 a 1700 & - & - & - & - & $11,1(1)$ \\
1701 a 1800 & - & - & - & - & $11,1(1)$ \\
\hline Total & $100(9)$ & $100(9)$ & $100(9)$ & $100(9)$ & $100(9)$ \\
\hline
\end{tabular}

Os valores entre parênteses indicam o número de amostras analisadas correspondentes ao percentual. Nível de detecção $=100 \mathrm{ng} / \mathrm{g}$. Tratamento $1=$ estádio fenológico $8 / 9$, início da fase de grãos para ensilagem de plantas inteiras, tratamento 2 = final do estádio fenológico 9, fase de grãos para ensilagem de plantas inteiras, tratamento $3=$ estádio fenológico 10, fase de ensilagem de grãos úmidos, tratamento $4=10$ dias após o estádio fenológico 10 , tratamento $5=20$ dias após o estádio fenológico 10 . Todas amostras foram coletadas em intervalos de 10 dias. 
Com relação ao desoxinivalenol, sua biossíntese foi de pouca intensidade nos dois experimentos. A toxina foi detectada no experimento de Arapoti apenas no tratamento 4 (11,1\% das amostras com níveis de contaminação entre 101 e $200 \mathrm{ng} / \mathrm{g})$, conforme Tabela 8. No ensaio conduzido em Castro, a toxina foi detectada em freqüências e intensidades de contaminação pouco maior em relação a Arapoti. A toxina apresentou-se positiva em $11,1 \%$ das amostras dos tratamento 1 e 4 ao nível de 101 a $200 \mathrm{ng} / \mathrm{g}$ e em $22,2 \%$ das amostras pertencentes ao tratamento $3(11,1 \%$ entre 101 e 200 ng/g - 11,1\% entre 201 e 300 ng/g), não sendo detectada nos tratamentos 2 e 5 (Tabelas 9).

Ressalta-se ainda que a produção de desoxinivalenol e zearalenona ocorreu simultaneamente em 11,1 e 10,0\% das amostras positivas para desoxinivalenol e/ou zearalenona, coletadas nos experimentos de Arapoti e Castro, respectivamente, cujos níveis de contaminação dos grãos por desoxinivalenol foram menores em relação a zearalenona (Tabela 10).

As micotoxinas ocratoxina A e a toxina T-2 não foram detectadas ao nível de $4 \mathrm{e}$ $100 \mathrm{ng} / \mathrm{g}$, respectivamente.

Tabela 8. Níveis de desoxinivalenol, por classe e por tratamento, determinados nas 45 amostras coletadas em Arapoti, PR, em 1998.

\begin{tabular}{lccccr}
\hline Classe (ng/g) & \multicolumn{5}{c}{$\%$ de amostras positivas para desoxinivalenol, por tratamento } \\
\cline { 2 - 6 } & 1 & 2 & 3 & 4 & 5 \\
\hline$<80$ & $100(9)$ & $100(9)$ & $100,0(9)$ & $88,9(8)$ & $100(9)$ \\
80 a 100 & - & - & - & - & - \\
101 a 200 & - & - & - & $11,1(1)$ & - \\
\hline Total & $100(9)$ & $100(9)$ & $100(9)$ & $100(9)$ & $100(9)$ \\
\hline
\end{tabular}

Os valores entre parênteses indicam o número de amostras analisadas correspondentes ao percentual. Nível de detecção $=80 \mathrm{ng} / \mathrm{g}$. Tratamento $1=$ estádio fenológico $8 / 9$, início da fase de grãos para ensilagem de plantas inteiras, tratamento 2 = final do estádio fenológico 9, fase de grãos para ensilagem de plantas inteiras, tratamento $3=$ estádio fenológico 10 , fase de ensilagem de grãos úmidos, tratumento $4=10$ dias após o estádio fenológico 10 , tratamento $5=20$ dias após o estádio fenológico 10 . Todas amostras foram coletadas em intervalos de 10 dias. 
Tabela 9. Níveis de desoxinivalenol por classe e por tratamento determinados 45 nas amostras coletadas em Castro, PR, em 1998.

\begin{tabular}{lccccc}
\hline Classe (ng/g) & \multicolumn{5}{c}{$\%$ de amostras positivas para desoxinivalenol, por tratamento } \\
\cline { 2 - 6 } & 1 & 2 & 3 & 4 & 5 \\
\hline$<80$ & $88,9(8)$ & $100(9)$ & $77,8(7)$ & $88,9(8)$ & $100,0(9)$ \\
80 a 100 & - & - & - & - & - \\
101 a 200 & $11,1(1)$ & - & $11,1(1)$ & $11,1(1)$ & - \\
201 a 300 & - & - & $11,1(1)$ & - & - \\
\hline Total & $100(9)$ & $100(9)$ & $100(9)$ & $100(9)$ & $100(9)$ \\
\hline
\end{tabular}

Os valores entre parênteses indicam o número de amostras analisadas correspondentes ao percentual. Nível de detecção $=80 \mathrm{ng} / \mathrm{g}$. Tratamento $1=$ estádio fenológico $8 / 9$, início da fase de grāos para ensilagem de plantas inteiras, tratamento 2 = final do estádio fenológico 9, fase de gräos para ensilagem de plantas inteiras, tratamento $3=$ estádio fenológico 10 , fase de ensilagem de grãos úmidos, tratamento $4=10$ dias após o estádio fenológico 10, tratamento 5= 20 dias após o estádio fenológico 10. Todas amostras foram coletadas em intervalos de 10 dias.

Tabela 10. Níveis de micotoxinas das amostras que apresentaram ocorrência simultânea de zearalenona e desoxinivalenol (ng/g), do total de 90 amostras analisadas de Arapoti e Castro, em 1998.

\begin{tabular}{cccc}
\hline \multicolumn{2}{c}{ Arapoti } & \multicolumn{2}{c}{ Castro } \\
\hline Zearalenona (ng/g) & Desoxinivalenol $(\mathrm{ng} / \mathrm{g})$ & Zearalenona(ng/g) & Desoxinivalenol(ng/g) \\
\hline 449 & 154 & 979 & 272 \\
- & - & 551 & 115 \\
\hline
\end{tabular}

Total de amostras positivas para zearalenona e, ou desoxinivalenol: Arapoti $=9$, Castro $=20$. 


\section{DISCUSSĀO}

A comparação dos resultados obtidos evidenciou que a contaminação de grãos de milho no campo, por aflatoxinas, foi baixa, concordando com os dados obtidos por Scussel et al. (1986). Os mesmos autores não encontraram resultados positivos ao analisar aflatoxina nas amostras de quatro cultivares de milho, coletadas à 25,40 e 70 dias após a polinização.

A ocorrência de baixos níveis de contaminação de aflatoxinas pode ser explicada pelas condições ambientais de temperatura e chuva, estádio de maturidade de grãos e competição füngica de ocorrência natural

As temperaturas máximas e mínimas médias observadas em Arapoti e Castro, por decêndio, a partir da emissão dos estilo-estigmas de milho (Anexos A e B), foram mais baixas em relação às temperaturas altemadas de 32 a $38^{\circ} \mathrm{C} / 21$ a $26^{\circ} \mathrm{C}$, as quais favorecem a infecção dos estilo-estigmas por A. flavus (Jones et al., 1980), bem como a produção de aflatoxinas (Payane, 1992). Ainda, os resultados obtidos estão em concordância com Bosque (1996), que encontraram aflatoxinas em condições de campo, quando o período entre o florescimento e a maturidade coincidiu com a ocorrência de temperaturas mínimas médias de $22-24^{\circ} \mathrm{C}$, o mesmo não acontecendo com temperaturas inferiores a $16^{\circ} \mathrm{C}$.

A umidade elevada favorece a biossintese de aflatoxinas (Gourama \& Bullerman, 1995), contudo, o período entre o florescimento do milho e o estádio de grãos pastosos coincidiu com chuvas intensas (Anexos A e B), que segundo Lillehoj et al. (1978), Zuber \& Lillehoj (1979) e Jones et al. (1981) não é favorável à produção final de aflatoxinas.

Os trabalhos de Kawashina et al. (1993) sugerem que a biossíntese de aflatoxina $B_{1}$ depende também dos estádios em que os grãos de milho se encontram, sendo 
favorecida em grãos maturos, apesar de verificarem menor infecção de $A$. flavus nesse estádio, fato que também pode explicar a baixa contaminação de milho por aflatoxinas no campo, antes do momento da colheita de grãos.

A competição entre fungos é outro fator que pode determinar a predominância da contaminação de micotoxinas de grãos de milho. Na região, na qual foi desenvolvido o presente trabalho, pode-se isolar fungos do gênero Fusarium spp., F. moniliforme, Penicillium spp e Aspergillus spp de amostras de milho coletadas imediatamente após a colheita, independentemente de genótipos (Homechin et al., 1996 e Hirooka et al., 1996). De acordo com Hill et al. (1985), Rheeder et al., (1990), Sydenham et al. (1990) e Doko et al. (1996) há correlação negativa entre a ocorrência de $A$. flavus e $F$. moniliforme e a ocorrência de $F$. moniliforme e $F$. graminearum em grãos de milho. Esse fato também pode estar associado ao baixo nível de contaminação das amostras de milho por aflatoxinas, conforme mostram as Tabelas 4 e 5 .

A contaminação dos grãos de milho por zearalenona no campo, a qual foi detectada nos dois locais em maior intensidade em relação às micotoxinas analisadas (Tabelas 6 e 7), também pode ser explicada pelas características ambientais relativas à temperatura, umidade e presença de espécies de fungos toxigênicos competitivos de ocorrência natural, conforme apontadas nos trabalhos listados no parágrafo anterior.

As temperaturas máximas e mínimas médias, por decêndio, observadas em Castro, a partir da emissão dos estilo-estigmas do milho, estiveram mais próximas, em relação a Arapoti (Anexos A e B), das temperaturas médias máximas de $26^{\circ} \mathrm{C}$ e médias mínimas de $16^{\circ} \mathrm{C}$, observadas no campo por Siame \& Lovelace (1994), quando o milho apresentava-se com alta infestação de $F$. graminearum. Ainda, as temperaturas observadas em Castro, em relação a Arapoti, também estiveram mais próximas das temperaturas alternadas de $24^{\circ} \mathrm{C} / 12^{\circ} \mathrm{C}$, situação esta, na qual Bilgrami et al. (1995) observaram as maiores produções da toxina, por F. graminearum BULM 102, incubado em substrato de arroz, e das temperaturas alternadas de $28^{\circ} \mathrm{C} / 12^{\circ} \mathrm{C}$, ambiente no qual Jiménez et al. (1996) obtiveram alta produção de zearalenona ao incubar $F$. graminearum em substrato de milho. Assim, as condições ambientais de temperatura, registradas nos locais de coleta de amostras, estão de acordo com a predominância de 
contaminação de grãos de milho por zearalenona, verificada nas avaliações, conforme pode ser observado nas Tabelas 6 e 7. De acordo com Siame \& Lovelace (1994), a biossíntese de zearalenona é favorecida por temperaturas entre 12 e $16^{\circ} \mathrm{C}$, sendo que essa condição foi registrada apenas no primeiro decêndio, durante o período compreendido a partir da emissão dos estilo-estigmas até o tratamento 5, no local Arapoti, e no último decêndio, para o local Castro (Anexos A e B), não havendo assim, plena concordância entre os resultados obtidos.

As chuvas registradas, foram abundantes durante o período de floração do milho até a coleta das amostras do tratamento 5 , em ambos locais, sendo mais intensas em Castro em relação a Arapoti (Anexos A e B), cuja condição de umidade elevada tornou favorável a biossíntese de zearalenona, corroborando os resultados obtidos por Eugenio et al. (1970), Sherwood \& Peberdy (1974), Martins (1994) e Bilgrami et al. (1995).

Da mesma forma, a contaminação dos grãos de milho por desoxinivalenol no campo, constatada nos experimentos (Tabelas 8 e 9), apoia-se nas condições ambientais de temperatura e umidade e na presença de espécies de fungos toxigênicos competitivos de ocorrência natural, conforme anteriormente discutido.

Assim, observou-se contaminação mais intensa por desoxinivalenol em Castro, onde as temperaturas máximas e mínimas médias, por decêndio, estiveram mais próximas, em relação a Arapoti, a partir da emissão dos estilo-estigmas do milho, (Anexos A e B), das temperaturas médias máximas de $26^{\circ} \mathrm{C}$ e médias mínimas de $16^{\circ} \mathrm{C}$, observadas no campo por Siame \& Lovelace (1994), quando o milho apresentava-se com alta infestação de $F$. graminearum, bem como das temperaturas alternadas de $25^{\circ} \mathrm{C} / 12^{\circ} \mathrm{C}$, condição na qual Bilgrami et al. (1995) observaram as maiores produções da referida toxina por $F$. graminearum BULM 102, incubado em substrato de arroz.

Todavia, a condição de freqüentes chuvas, durante a fase de emissão dos estilo-estigmas até o estádio inicial de enchimento de grãos, parecem viabilizar a infecção e colonização do milho, o que pode discordar com as observações de Koehler (1959), Tuite et al. (1974) e Sutton (1982) em relação ao $F$. graminearum, apesar de não ter sido avaliado a presença de fungos toxigênicos nas amostras de grãos coletadas nos experimentos. De outra parte, de acordo com Bilgrami et al. (1995), a umidade elevada 
do substrato constitui-se em condição favorável para a produção de desoxinivalenol por F. graminearum BULM 102, concordando com as condições de alta umidade, expressa em chuvas, verificadas nos locais onde o trabalho foi conduzido (Anexos A e B).

O fato da ocorrência simultânea de zearalenona e desoxinivalenol nas amostras analisadas, bem como suas proporções, conforme apresentado na Tabela 10, concordam com os resultados obtidos por Siame \& Lovelace (1994), ao incubar F. graminearum, em substrato de milho moído, em temperaturas alternadas de $26^{\circ} \mathrm{C} / 16^{\circ} \mathrm{C}$.

As ocratoxinas são micotoxinas produzidas em condições de alta umidade (Marquardt \& Frohlich, 1992), sendo que as condições favoráveis para o desenvolvimento de seus sintetizadores, $A$. alutaceus e $P$. verrucosum, estão relacionados à temperaturas entre $12^{\circ} \mathrm{C}$ e $37^{\circ} \mathrm{C}$ (ótimo de $25^{\circ} \mathrm{C}$ ) e entre 4 e $31^{\circ} \mathrm{C}$ (ótimo $24^{\circ} \mathrm{C}$ ), respectivamente (Moss, 1996). Apesar das condições de temperatura e umidade constatadas no presente trabalho estarem inseridas no intervalo, no qual a biossíntese de ocratoxina A é possível, a mesma não foi detectada ao nível de $4 \mathrm{ng} / \mathrm{g}$.

Ainda, como a cultura foi conduzida no sistema de plantio direto, é bem provável que, em ambientes de grande diversidade biológica, ocorram mecanismos de autorregulação, resultando na predominância de um pequeno número de espécies de fungos toxigênicos, em detrimento de outras espécies potenciais, mesmo que as condições de umidade e temperatura sejam favoráveis à todas. Assim, de acordo com Marquardt \& Frohlich (1992) a presença de microflora não produtora de ocratoxina A em grãos de cevada suprime a biossíntese da ocratoxina A por $A$. alutaceus. Da mesma forma, para Ramakrishna et al. (1996b), a produção de ocratoxina A por $P$. verrucosum, em cevada, em geral foi inibida, às vezes significativamente, quando na presença de A. flavus, e levemente inibida quando estava na presença de $F$. sporotrichioides, ocorrendo em alguns momentos, o aumento temporário da toxina durante o período de incubação.

Igualmente, a toxina T-2 não foi detectada nas 90 amostras de milho analisadas, concordando com Marasas et. al. (1984), os quais afirmam que as condições ótimas para a biossíntese da toxina em discussão, são ambientes com alta umidade e temperaturas entre 8 e $10^{\circ} \mathrm{C}$. Contudo, as referidas condições foram verificadas apenas para umidade, 
nos locais de origem das amostras analisadas (Anexos A e B). De outra parte, Bilgrami et. al. (1995) demonstrou ser possível a produção da toxina em temperaturas altemadas de $27^{\circ} \mathrm{C}$ durante o dia com $16^{\circ} \mathrm{C}$ durante à noite, ao incubar $F$. sporotrichioides BULM 110 em substrato de arroz polido, condição de temperatura próxima àquela verificada em Castro, de origem das amostras analisadas no presente trabalho. Ainda, o fato da não detecção da toxina T-2 pode estar relacionada também a possível não presença de fungos sintetizadores e, de acordo com Kotsonis \& Ellison (1975), citados por Ramakrishna (1996a), a referida toxina pode ser transformada em micotoxina HT-2, quando as temperaturas variam de 20 para $30^{\circ} \mathrm{C}$, cuja condição semelhante à descrita, foi observada em Arapoti (Anexo A).

De acordo com Jones et al. (1981) a planta de milho toma-se mais vulnerável à contaminação de grãos por micotoxinas, quando é submetida a estresse a partir da fase de floração. Ainda, Fancelli \& Dourado-Neto (1997) citam que a redução da luminosidade e o excesso de chuvas a partir do florescimento do milho, especialmente nos quinze dias seguintes à fecundação, levam a planta à condição de estresse, podendo favorecer a incidência de fungos, entre esses, àqueles pertencentes ao gênero Fusarium. As condições de baixa luminosidade e excesso de água estiverem evidenciadas em Castro, local onde esses dados foram coletados, durante a maior parte do período compreendido entre o início da emergência dos estilo-estigmas e a última coleta de amostras, conforme mostra o Anexo C. Assim, a condição da planta, pode ter favorecido a ocorrência, predominantemente, de zearalenona e desoxinivalenol, além dos outros fatores discutidos anteriormente.

\subsection{Considerações finais}

A contaminação natural de grãos de milho por zearalenona e desoxinivalenol no campo, antes da colheita mecânica, em níveis detectáveis, pode ocorrer em ambientes com temperaturas médias mínimas e máximas, respectivamente entre $16^{\circ} \mathrm{C}$ e $34^{\circ} \mathrm{C}$ ou 
$15^{\circ} \mathrm{C}$ e $31^{\circ} \mathrm{C}$, associadas a umidade elevada, com chuvas intensas, a partir do início da emissão dos estilo-estigmas.

Para essas condições ambientais particulares, pode-se inferir que o método de controle por evasão das micotoxinas aflatoxinas, ocratoxina $\mathrm{A}$, zearalenona, toxina $\mathrm{T}-2 \mathrm{e}$ desoxinivalenol, terá maior probabilidade de êxito quando o milho é destinado ao processo de ensilagem de plantas inteiras.

Ainda, destaca-se que existe grande possibilidade de contaminação de grãos de milho por zearalenona e desoxinivalenol, em níveis detectáveis, no momento da colheita para o processo de grãos úmidos. Da mesma forma, o risco de contaminação dos grãos de milho por micotoxinas, no campo, pode aumentar com o atraso da colheita. 


\section{CONCLUSÕES}

Considerando-se as condições em que este trabalho foi desenvolvido, dentro de sua localização geográfica, os resultados obtidos permitiram as seguintes conclusões:

a) as aflatoxinas contarninam grãos de milho após o estádio fenológico 10 (maturidade fisiológica).

b) a zearalenona contamina grãos de milho a partir do final do estádio fenológico 9 (grãos "duros")

c) o desoxinivalenol contamina grãos de milho a partir do final do estádio fenológico 8 (formação de "dentes").

d) na cultura de milho, o método de controle de micotoxinas por evasão não é totalmente seguro, necessitando do desenvolvimento e/ou da utilização de outras técnicas, combinadas, para evitar a contaminação de grãos de milho por micotoxinas, no campo, especialmente, àquelas sintetizadas por Fusarium spp. 
ANEXOS 
Anexo A. Temperaturas médias mínimas, médias máximas, e chuvas observadas em Arapoti, PR, em 1997/1998, a partir do início da emergência dos estilo-estigmas até a última coleta de amostras.

\begin{tabular}{|c|c|c|c|c|}
\hline \multirow[t]{2}{*}{ Decêndio } & \multicolumn{2}{|c|}{$\begin{array}{l}\text { Temperaturas médias } \\
\left({ }^{\circ} \mathrm{C}\right)\end{array}$} & \multirow{2}{*}{$\begin{array}{l}\text { Chuvas } \\
\text { (mm) } \\
\text { Soma }\end{array}$} & \multirow[t]{2}{*}{ Observações } \\
\hline & Mínima & Máxima & & \\
\hline $22 / 11$ a $02 / 12 / 97$ & 16 & 26 & 63,0 & Início emergência estilo-estigma \\
\hline $03 / 12$ a $12 / 12 / 97$ & 18 & 28 & 7,0 & - \\
\hline $13 / 12$ a $22 / 12 / 97$ & 18 & 30 & 26,7 & - \\
\hline $23 / 12$ a $01 / 01 / 98$ & 21 & 34 & 33,0 & - \\
\hline $02 / 01$ a $11 / 01 / 98$ & 19 & 32 & 115,0 & - \\
\hline $12 / 01$ a $21 / 01 / 98$ & 19 & 31 & 7,5 & Decêndio anterior ao tratamento 1 \\
\hline $22 / 01$ a $31 / 01 / 98$ & 22 & 31 & 4,3 & Decêndio anterior ao tratamento 2 \\
\hline $01 / 02$ a $10 / 02 / 98$ & 20 & 29 & 58,3 & Decêndio anterior ao tratamento 3 \\
\hline $11 / 02$ a $20 / 02 / 98$ & 17 & 25 & 85,3 & Decêndio anterior ao tratamento 4 \\
\hline $21 / 02$ a 02/03/98 & 19 & 27 & 205,3 & Decêndio anterior ao tratamento 5 \\
\hline \multicolumn{5}{|c|}{$\begin{array}{l}\text { Temperatura média mínima }=19^{\circ} \mathrm{C} \text {, média máxima }=29^{\circ} \mathrm{C} \text {, mínima do período }=16^{\circ} \mathrm{C} \text { e máxima do } \\
\text { período }=34^{\circ} \mathrm{C} \text {, total de chuva }=605,4 \mathrm{ml} \text {. Tratamento } 1=\text { estádio fenológico } 8 / 9 \text {, início da fase de grãos } \\
\text { para ensilagem de plantas inteiras, tratamento } 2=\text { final do estádio fenológico } 9 \text {, fase de grãos para } \\
\text { ensilagem de plantas inteiras, tratamento } 3=\text { estádio fenológico } 10 \text {, fase de ensilagem de grãos úmidos, } \\
\text { tratamento } 4=10 \text { dias após o estádio fenológico } 10 \text {, tratamento } 5=20 \text { dias após o estádio fenológico } 10 \text {. } \\
\text { Todas amostras foram coletadas em intervalos de } 10 \text { dias. }\end{array}$} \\
\hline
\end{tabular}


Anexo B. Temperaturas médias mínimas, médias máximas, e chuvas observadas em Castro, PR, em 1997/1998, a partir do início da emergência dos estilo-estigmas até a última coleta de amostras.

\begin{tabular}{|c|c|c|c|c|}
\hline \multirow[t]{2}{*}{ Decêndios } & \multicolumn{2}{|c|}{$\begin{array}{c}\text { Temperaturas médias } \\
\left({ }^{\circ} \mathrm{C}\right)\end{array}$} & \multirow{2}{*}{$\begin{array}{l}\text { Chuvas } \\
\text { (mm) } \\
\text { Soma }\end{array}$} & \multirow[t]{2}{*}{ Observações } \\
\hline & Mínima & máxima & & \\
\hline $19 / 12$ a $29 / 12 / 97$ & 17 & 29 & 77,9 & Início emergência estilo-estigma \\
\hline $30 / 12$ a $08 / 01 / 98$ & 19 & 29 & 163,6 & - \\
\hline $09 / 01$ a $18 / 01 / 98$ & 17 & 26 & 22,6 & - \\
\hline $19 / 01$ a 28/01/98 & 18 & 31 & 29,4 & - \\
\hline $29 / 01$ a $07 / 02 / 98$ & 19 & 29 & 81,9 & - \\
\hline 08/02 a 17/02/98 & 17 & 25 & 99,0 & Decêndio anterior ao tratamento 1 \\
\hline $18 / 02$ a $27 / 02 / 98$ & 18 & 29 & 73,1 & Decêndio anterior ao tratamento 2 \\
\hline $28 / 02$ a 09/03/98 & 17 & 29 & 112,6 & Decêndio anterior ao tratamento 3 \\
\hline $10 / 03$ a $19 / 03 / 98$ & 17 & 25 & 334,6 & Decêndio anterior ao tratamento 4 \\
\hline $20 / 03$ a $30 / 03 / 98$ & 15 & 26 & 88,0 & Decêndio anterior ao tratamento 5 \\
\hline \multicolumn{5}{|c|}{$\begin{array}{l}\text { Temperatura média mínima }=17^{\circ} \mathrm{C} \text { e média máxima }=28^{\circ} \mathrm{C} \text {, mínima do período }=15^{\circ} \mathrm{C} \text { e máxima do } \\
\text { período }=31^{\circ} \mathrm{C} \text {, total de chuva }=1.082,7 \text { ml. Tratamento } 1=\text { estádio fenológico } 8 / 9 \text {, início da fase de } \\
\text { grãos para ensilagem de plantas inteiras, tratamento } 2=\text { final do estádio fenológico } 9 \text {, fase de grãos para } \\
\text { ensilagem de plantas inteiras, tratamento } 3=\text { estádio fenológico } 10 \text {, fase de ensilagem de grãos úmidos, } \\
\text { tratamento } 4=10 \text { dias após o estádio fenológico } 10 \text {, tratamento } 5=20 \text { dias após o estádio fenológico } 10 \text {. } \\
\text { Todas amostras foram coletadas em intervalos de } 10 \text { dias. }\end{array}$} \\
\hline
\end{tabular}


Anexo C. Luminosidade média e média de chuvas diárias, por decêndio, observadas em Castro, PR, em 1997/1998, a partir do início da emergência dos estilo-estigmas até a última coleta de amostras.

\begin{tabular}{lrrc}
\hline Decêndios & $\begin{array}{c}\text { Luminosidade } \\
(\text { Watt/m2) }\end{array}$ & $\begin{array}{c}\text { Chuvas (mm) } \\
\text { média diária }\end{array}$ & Observações \\
\hline 19/12 a 29/12/97 & 428 & 7,8 & Início emergência estilo-estigma \\
30/12 a 08/01/98 & 391 & 16,4 & - \\
09/01 a 18/01/98 & - & 2,3 & - \\
$19 / 01$ a 28/01/98 & 444 & 2,9 & - \\
$29 / 01$ a 07/02/98 & 327 & 8,2 & \\
$08 / 02$ a 17/02/98 & 245 & 9,9 & Decêndio anterior ao tratamento 1 \\
$18 / 02$ a 27/02/98 & 313 & 7,3 & Decêndio anterior ao tratamento 2 \\
$28 / 02$ a 09/03/98 & 210 & 11,3 & Decêndio anterior ao tratamento 3 \\
$10 / 03$ a 19/03/98 & 110 & 33,5 & Decêndio anterior ao tratamento 4 \\
$20 / 03$ a 30/03/98 & 332 & 8,8 & Decêndio anterior ao tratamento 5 \\
\hline Obs: 1 = média do decêndio envolvendo o período luminoso do dia. Total de chuva = 1.082,7 ml. \\
Tratamento 1 = estádio fenológico 8/9, início da fase de grãos para ensilagem de plantas inteiras, \\
tratamento 2 = final do estádio fenológico 9, fase de grãos para ensilagem de plantas inteiras, tratamento 3 \\
= estádio fenológico 10, fase de ensilagem de grãos úmidos, tratamento 4 = 10 dias após o estádio \\
fenológico 10, tratamento $5=20$ dias após o estádio fenológico 10. Todas amostras foram coletadas em \\
intervalos de 10 dias.
\end{tabular}




\section{REFERÊNCIAS BIBLIOGRÁFICAS}

AGRIOS, G.N. Plant pathology. 4.ed. San Diego: Academic Press, 1997. p.351- 367. ANDESRSON, H.W.; NEHRING, E.W.; WICHSER, W.R. Aflatoxin contamination of corn in the field. Journal of Agricultural and Food Chemistry, v.23, n.4, p.775 782, 1975.

ANDRADE, F.; CIRILO, A.; UHART, S.; OTEGUI, M. Ecofisiología del cultivo de maíz. Local: Ed. La Barrosa, 1996. 292 p.

ASEVEDO, I.G.; GAMBALE, W.; CORRÊA, B.; PAULA, C.R.; ALMEIDA, R.M.A.; FRAMIL, V.M.S. Influence of temperature and relative humidity in the production of aflatoxins in samples of stored maize, artificially contamined with Aspergillus flavus (Link). Revista de Microbiologia, v.24, n.1, p.32-37, 1993.

BATTALGLIA, R.; HATZOLD, T.; KROES, R. Conclusions from the workshop on ochratoxin in food, organized by ILSI Europe in Aix-en-Provence (10-12 january 1996). Food Additives and Contaminants, v.13, p.1-3, 1996. Suppl.

BENNETT, G.A.; RICHARD, J.L. Influence of processing on Fusarium mycotoxins in contaminated grains. Food Technology, v.50, n.5, p.235-238, 1996.

BILGRAMI, K.S.; RANJAN, K.S.; SINHA, A.K. Impact of crop demage on occurrence of Aspergillus flavus and aflatoxin in rainy-season maize (Zea mays). Indian Journal of Agricultural Science, v.62, n.10, p.704-709, 1992.

BILGRAMI, K.S.; MASOOD, A.; SAHAY, S.S.; RAHMAN, M.F. Production of fusarial toxins under varying condictions. Indian Phytopathology, v.48, n.3, p.347-351, 1995.

BOSQUE, L.A.R. del. Impact of agronomic factors on aflatoxin contamination in preharvest field cor in northeastern mexico. Plant Disease, v.80, n.9, p.988-993, 1996. 
CHELKOWSKI, J.; GOLINSKI, P.; GODLEWSKA, B.; RADOMYSKA, W.; SZEBIOTKO, K.; WIEWIÓROWSKA, M. Mycotoxins in cereal grains. Part IV. Inactivaction of ocratoxin $A$ and other mycotoxins during ammoniation. Nahrung v.25, p.631, 1981 .

CHELKOWSKI, J.; SZEBIOTKO, K.; GOLINSKI, P.; BUCHOWSKI, M.; GODLEWSKA, B.; RADOMYSKA, W.; WIEWIÓROWSKA, M. Mycotoxins in cereal grains. Part V. Changes of cereal grain biological value after ammoniation and mycotoxins inactivation. Nahrung v.26, p.1, 1982.

COLE, R.J.; COX, R.H. Handbook of toxic fungal metabolites. New York: Academic Press, 1981. 937 p.

COMPANY, M. L. El maiz. Madrid: Mundi-Prensa, 1984. 318p.

COULOMBE Jr., R. J. Biological action of mycotoxins. Journal of Dairy Science, v.76, n.3, p.880-891, 1993.

DESJARDINS, ANNE E.; HOHN, T.M.; McCORMICK, S.P. Trichothecene biosynthesis in Fusarium species: chemistry, genetics and significance. Microbiological Reviews, v.57, n.3, p.595-604, 1993.

DIEKMAN, M.A.; GREEN, M.L. Mycotoxins and reproduction in domestic livestock. Journal of Animal Science, v.70, p.1615-1627, 1992.

DOKO, M.B.; CANET, C.; BROWN, N.; SYDENHAM, E.W.; MPUCHANE, S.; SIAME, B.A. Natural co-ocurrence of fumonisins and zearalenone in cereals and cereal-based foods from eastern and southern Africa. Journal of Agricultural and Food Chemistry, v.44, n.10, p.3240-3243, 1996.

DOLLEAR, F.B.; MANN, G.E.; CODIFER Jr., L.P.; GARDNER Jr., H.K.; KOLTUN, P.; VIX, H.L.E. Elimination of aflatoxins from peanut meal. Journal American Oil Chemists Society, v.45, p.862-865, 1968.

DOYLE, M.P.; APPLEBAUM, R.S.; BRACKETT, R.E.; MARTH, E.H. Physical, chemical and biological degradation of mycotoxins in foods and agricultural commodities. Journal of Food Protection, v.45, n.10, p.964-1, 1982. 
EUGENIO, C.P.; CHRISTENSEN, C.M.; MIROCHA, C.J. Factors affecting production of the mycotoxin F-2 by Fusarium graminearum. Phytopathology, v.60, p.1055-1057, 1970.

FANCELLI, A.L.; DOURADO NETO, D. Milho: fisiologia da produção. In: SEMINÁRIO SOBRE FISIOLOGIA DA PRODUÇÃO E MANEJO DE ÁGUA E DE NUTRIENIES NA CULTURA DO MILHO DE ALTA PRODUTIVIDADE, Piracicaba, 1996. Piracicaba: ESALQ, POTAFOS, 1996. p.1-29.

FANCELLI, A.L.; DOURADO NETO, D. Tecnologia da produção de milho. Piracicaba: Publique, 1997. 174 p.

FAO. BOLETÍN TRIMESTRAL DE ESTADISTICAS, v.11, n.1/2, 1998. 107p.

FAO. PRODUCTION YEARBOOCK, v.50, 1996. 235p.

FIORENTIN, L.; FREITAS, A.R. de.; FIALHO, E.T. Contaminação por aflatoxinas em milho utilizado em rações para suínos. Pesquisa Agropecuária Brasileira, v.24, n.10, p.1211-1216, 1989.

FIORENTIN, L.; SONCINI, R.A.; SOBESTIANSKY, J.; MORES, N.; OLIVEIRA, J.A. de. Aflatoxicose em suínos. Relato de uma ocorrência natural. Arquivo Brasileiro de Medicina Veterinária e Zootecnia, v.38, n.1, p.11-16, 1986.

FONSECA, H.; NOGUEIRA, J.N.; GRANER, M.; OLIVEIRA, A.J.; CARUSO, J.G.B.; BORALLI, M.A.; CALORI, M.A.; KHATOUNIAN, C.A. Natural ocurrence of mycotoxins in some Brazilian foods. In: INTERNATIONAL SYMPOSIUM ON MYCOTOXIN AND PHYCOTOXINS, 5, Vienna, 1982. Proceedings. Vienna: World Health Organization, 1982. p.76-79.

FONSECA, H.; NOGUEIRA, J.N.; GRANER, M.; OLIVEIRA, A.J.; CARUSO, J.G.B.; BORALLI, M.A.; CALORI, M.A.; KHATOUNIAN, C.A. Natural ocurrence of mycotoxins in some Brazilian foods. Part II. In: WORLD CONGRESS OF FOOD SCIENCE AND TECHNOLOGY, 6., Dublin, 1983. Proceedings. Dublin: Boole Press, 1983. p. 53-54.

FONSECA, H. Aflatoxin removal from peanut meals with commercial aqueous ethyl alcohol. Revista de microbiologia, v.25, n.2, p.101-106, 1994. 
GLORIA, E. M. da. Ocorrência de aflatoxinas, zearalenona e ocratoxina A, no milho, a ser utilizado como matéria prima em indústria alimentícia do estado de São Paulo. Piracicaba, 1995. 71p. Dissertação (Mestrado)-Escola Superior de Agricultura 'Luiz de Queiroz', Universidade de São Paulo.

GOURAMA, N.; BULLERMAN, L.B. Aspergillus flavus and Aspergillus parasiticus: Aflatoxigenic fungi of concern in foods and feeds: A review. Journal of Food Protection, v.58, n.12, p.1395-1404, 1995.

GRABARKIEWICZ-SZCZESNA, J.; FOREMSKA, E.; GOLINSKI, P. Distribution of trichothecene mycotoxins in maize ears infected with $F$. graminearum and $F$. crookwellense. Mycotoxin Research, v.12, n.1, p.45-51, 1996.

GREENHALGH, R.; NEISH, G.A.; MILLER, J.D. Deoxynivalenol, acetyl deoxynivalenol and zearalenone formation by canadian isolates of Fusarium graminearum on solid substrates. Applied and Environmental Microbiology, v.46, n.3, p.625-629, 1983.

HENNIGEN, M.R.; DICK, T. Incidence and abundance of mycotoxins in maize in Rio Grande do Sul, Brazil. Food Additives and Contaminants, v.12, n.5, p.677-681, 1995.

HILL, R.A.; WILSON, D.M.; McMILIAN, W.W.; WIDSTROM, N.W.; COLE, R.J.; SANDERS, T.H.; BLANKENSHIP, P.D. Ecology of the Aspergillus flavus group and aflatoxin formation in maize and groundnut. In: LACEY, J. Trichothenes and other mycotoxins. London: John Wiley, 1985.

HIROOKA, E.Y.; YAMAGUCHI, M.M.; AOYAMA, S.; SUGIURA, Y.; UENO, Y. The natural ocurrence of furnonisins in brazilian corn kernels. Food Additives and Contaminants, v.13, n.2, p.173-183, 1996.

HOMECHIN, M.; HIROOKA, E.Y.; ONO, E.Y.S.; COSTA, J.M.; SIMIONATO, A.A.; MOLIN, R. Microorganismos associados a grãos de milho, produzidos nas regiões de Castro e Campo Mourão-Pr na safra 1994/95. In: CONGRESSO NACIONAL DE MILHO E SORGO, 21., Londrina, 1996. Resumos. Londrina: IAPAR, 1996. p.272. 
JMÉNEZ, M.; MÁÑEZ, M.; HERNÁNDEZ, E. Influence of water activity and temperature on the production of zearalenone in corn by three Fusarium species. International Journal of Food Microbiology, v.29, p.417-421, 1996.

JONES, R.K.; DUNCAN, H.E.; PAYNE, G.A.; LEONARD, K.J. Factors influencing infection by Aspergillus flavus in silk-inoculeted corn. Plant Disease, v.64, p.859 863, 1980.

JONES, R.K.; DUNCAN, H.E.; HAMILTON, P.B. Planting date, harvest date, and irrigation effects on infection and aflatoxin production by Aspergillus flavus in field corn. Phytopathology, v.71, n.8, p.810-816, 1981.

JONES, F.T.; HAGLER, W.H.; HAMILTON, P.B. Association of low of aflatoxin in feed with productivity losses in commercial broiler operations. Poultry Science, v.61. p.861-868, 1982.

KARUNARATNE, A.; WEZENBERG, E.; BULLERMAN, L.B. Inhibithion of mold growth and aflatoxin production by Lactobacillus spp. Journal of Food Protection, v.53, p.230-236, 1990.

KAWASHIMA, K.; SIRIACHA, P.; KAWASUGI, S. Infection of Thai maize with Aspergillus flavus. JARQ, v.27, p.55-60, 1993.

KOEHLER, B. Corn ear disease in Illinois. Illinois: (Agricultural Experiment Station Bulletin, 639), 1959. 87p.

KOEPPEN, W. Grundriss der Klimakunde. Zweite verbesserte auflage der "Klimate der Erde". Berlin: Walter De Gruite Co, 1931.

KUIPER-GOODMAN, T. Risk assessment of ochratoxin A: an update. Food Additives and Contaminants, v.13, p.53-57, 1996. Suppl.

LAZZARI, F.A. A importância das micotoxinas na qualidade de grãos de milho para alimentação. In: SEMINÁRIO SOBRE A CULTURA DO MILHO SAFRINHA, 3, Assis, 1995. Resumos. Campinas: Instituto Agronômico, 1995. p.1-8.

LAZZARI, F.A. Umidade, fungos e micotoxinas na qualidade de sementes, grãos e rações. 2.ed. Curitiba: Ed. do Autor, 1997. 134 p. 
LILLEHOJ, E.B.; KWOLEK, W.R.; ZUBER, M.S.; CALVERT, O.H.; HORNER, E.S.; WIDSTROM, N.W.; GUTHRIE, W.D.; SCOTT, G.E.; THOMPSON, D.L.; FINDLEY, W.R.; BOCKHOLT, A.J. Aflatoxin contamination of field corn; evalution of regional $t$ est plots for early detection. Cereal Chemistry, v.55, p.1007-1013, 1978.

LINDENFELSER, L.A.; CIEGLER, A. Studies on aflatoxin detoxification in shelled corn by ensiling. Journal of Agricultural and Food Chemistry, v.18, n.4, p.640 643, 1970.

MADHYASTHA, S.M.; MARQUARDT, R.R.; FROHLICH, A.A.; PLATFORD, G.; ABRAMSON, D. Effects of different cereal and oilseed substrates on the growth and production of toxins by Aspergillus alutaceus and Penicillium verrucosum. Journal of Agricultural and Food Chemistry, v.38, p.1505-1510, 1990.

MADSEN, A.; HALD, B; MORTENSEN, H.P. Feeding experiments with ochratoxin A contaminated barley for bacon pigs-3. Detoxification by ammoniation heating $+\mathrm{NaOH}$, or autoclaving. Acta Agric. Scand., v.33, p171, 1983.

MANDARINO, J.M.G.; COELHO, D.T.; GOMES, J.C. Processos de detoxificação de milho (Zea mays L.). Arquivos de Biologia e Tecnologia, v.31, n.3, p.395-407, 1988.

MANDARINO, J.M.G.; COELHO, D.T.; GOMES, J.C.; PARREIRAS, J.F.M. Detoxificação de milho (Zea mays L.) contaminado com aflatoxinas através do processamento por extrusão termoplástica. Semina, v.10, n.1, p.6-11, 1989.

MARASAS, W.F.O., NELSON, P.E.; TOUSSOUN, T.A. Toxigenic Fusarium species: identity and mycotoxicology. University Park: The Pennsylvania State University Press, 1984.

MARQUARDT, R.R \& FROHLICH, A.A. A review of recent advances in understing ochratoxicosis. Journal of animal science, v.70, p.3968-3988, 1992.

MARTINS, M.L. Optimização das condições de produção de zearalenona por Fusarium graminearum em diferentes substratos naturais. Revista Portuguesa de Ciências Veterinárias, v.89, n.510, p.88-92, 1994. 
MENEGAZZO, R.; LAZZARI, F.A. Micotoxinas, em milho para rações, na região sul do Brasil. In: CONGRESSO NACIONAL DE MLHO E SORGO, 21, Londrina, 1996. Resumos. Londrina: Iapar, 1996. p.341.

MILLER, J.D. Fungi and mycotoxins in grain: Implications for stored product research. Journal of Stored Product Research, v.31, n.1, p.1-16, 1995.

MONTEIRO, J.A.; CRUZ, J.C.; BAHIA, F.G.F.T.C.; SANTANA, D.P.; GARCIA, J.C.; SANS, L.M.A.; BAHIA FILHO, A.F.C. Produção de milho no Brasil: realidade e perspectiva. In: CONGRESSO NACIONAL DO MLHO E SORGO, 19, Porto Alegre, 1992. Conferências. Porto Alegre: SAA, 1992. p.81-126.

MORAIS, S.A.; SILVA, R.D.M.; FONSECA, H.; DOMINGUES, M.A.C. A utilização de alumino-silicatos como agentes protetores contra a aflatoxicose na alimentação de frangos de corte. Scientia Agricola, v.50, n.2, p.311-320, 1993.

MOSS, M.O. Mode of formation of ochratoxin A. Food Additives and Contaminants, v.13, p.5-9, 1996. Suppl.

NELSON, P.E.; DESJARDINS, A.E.; PLATTNER, R.D. Fumonisins, mycotoxins produced by Fusarium spocies: biology, chimestry, and significance. Annual Review of Phytopathology, v.31, p. 233-252, 1993.

NIJS, M. de; ROMBOUTS, F.; NOTERMANS, S. Fusarium molds and their mycotoxins. Journal of Food Safety, v.16, p.15-58, 1996.

PAYNE, G.A. Aflatoxin in maize. Critical Reviews in Plant Sciences, v.10, n.5, p.423-440, 1992.

PEREIRA, O.A.P. Doenças do milho. In: KMMATI, H.; AMORIN, L.; BERGAMIN, FILHO, A.; CAMARGO, L.E.A.; REZENDE, J.A.M. Manual de fitopatologia: doenças de plantas cultivadas. São Paulo: Agronômica Ceres, 1997. v.2, p.538-555. POZZI, C.R.; CORREA, B.; GAMBALE, W.; PAULA, C.R.; CHACON-RECHE, N.O.; MEIRELLES, M.C.A. Postharvest and stored corn in Brazil: mycoflora interaction, abiotic factors and mycotoxin occurrence. Food Additives and Contaminants, v.12, n.3, p.313-319, 1995. 
PRADO, G. Incidência de aflatoxina $B_{1}$ em alimentos. Revista de Farmácia e Bioquímica, v.5, n.2, p.147-157, 1983.

PRADO, G.; MARTINS-VIEIRA, M.B.C.; SANTOS, J.P.; NICÁCIO, M.A.S. Ocorrência de micotoxinas em milho pós-colheita e armazenado no Estado de Minas Gerais, safra 1991. Parte I. In: CONGRESSO BRASILEIRO DE CIÊNCIA E TECNOLOGIA DE ALIMENTOS, 13., São Paulo, 1992. Anais. São Paulo: Sociedade Brasileira de Ciência e Tecnologia de Alimentos, 1992. p.41.

PRADO, G.; VIEIRA, M.B.C.M.; SANTOS, J.P.; OLIVEIRA, M.S. da. Ocorrência de micotoxinas em milho pós-colheita e armazenado do estado de Minas Gerais, safra 1991. Higiene Alimentar, v.9, n.35, p.24-27, 1995.

PRADO, G.; OLIVEIRA, M.S.; FERREIRA, S.O.; CORRÊA, T.B.S.; AFFONSO, B.R.R. Ocorrência natural de desoxinivalenol e toxina T-2 em milho pós-colheita. Ciência e Tecnologia de Alimentos, v.17, n.3, p.259-262, 1997.

RAMAKRISHNA, N.; LACEY, J.; SMITH, J.E. Colonization of barley grain by Penicillium verrucosum and ochratoxin A formation in the presence of competing fungi. Journal of Food Protection, v.59, n.12, p.1311-1317, $1996 \mathrm{~b}$.

RAMAKRISHNA, N.; LACEY, J.; SMITH, J.E. The effects of fungal competition on colonization of barley grain by Fusarium sporotrichioides on T-2 toxin formation. Food Additives and Contaminants, v.13, n.8, p.939-948, 1996a.

RAMOS, A.J., HERNÃNDEZ, E. Reduccion de los niveles de aflatoxinas y otras micotoxinas en alimentos mediante métodos físicos, químicos y biologicos. Alimentaria, v.28, n.225, p.45-55, 1991.

RAMOS, A,J.; GREMMELS, J.F.; HERNÁNDEZ, E. Prevention of toxic effects of mycotoxins by means of nonnutritive adsorbent compounds. Journal of Food Protection, v.59, n.6, p.631-641, 1996.

REID, L.M.; MATHER, D.E.; HAMILTON, R.I. Distribution of deoxynivalenol in Fusarium graminearum-infected maize ears. Phytopathology, v.86, n.1, p.110-114, 1996.

REIS, E.M.; CASA, R.T. Manual de identificação e controle de doenças de milho. Passo Fundo: Aldeia Norte Editora, 1996. 80p. 
REIS, E.M.; FORCELINI, C.A. Controle cultural In: BERGAMIN FILHO, A. KIMATI, H.; AMORIN, L. Manual de fitopatologia. 3.ed. São Paulo: Agronômica Ceres, 1995. v.1, p.710-716.

RHEEDER, J.P.; MARASAS, W.F.O.; VAN WYK, P.S. Fungal association in corn kernels and effects on germination. Phytopathology, v.80, p.131-134, 1990.

ROTTER, R.G.; MARQUARDT, R.R.; FROHLICH, A.A.; ABRAMSON, D. Ensiling as a means of reducing ochratoxin A concentracions in contaminated barley. Journal of Science of Food and Agriculture., v.50, p.155, 1990.

ROMER, R.T. Use of small charcoaValumina cleanup colums in determination of trichothecene mycotoxins in foods and feeds. Journal of the Association of Official Analytical Chemists, v.69, n.4, p.699-703, 1986.

SABINO, M.; PRADO, G.; COLEN, G. Ocorrência de aflatoxinas, ocratoxina A e zearalenona em milho de Minas Gerais. Parte 1. Revista do Instituto Adolfo Lutz, v.46, n.1/2, p.65-71, 1986.

SABINO, M.; PRADO, G.; INOMATA, E.I.; PEDROSO, M.O.; GARCIA, R.V. Natural occurence of aflatoxinas and zearalenone in maize in Brazil. Part II. Food Aditives and Contaminants, v. 6, p.327-331, 1989.

SAMARAJEEWA, U.; SEN, A.C.; COHEN, M.D.; WEI, C.I. Detoxification of aflatoxins in foods and feeds by physical and chemical methods. Journal of Food Protection, v.53, n.6, p.489-502, 1990.

SANTOS, J.L. de; SILVA, J.C.P. da; RIBEIRO, M.F.B.; FARIA, J.E. de. Aflatoxicose em suíno: ocorrência de surtos na Zona da Mata de Minas Gerais. Arquivo Brasileiro de Medicina Veterinária e Zootecnia, v.38, n.2, p.167-172, 1986.

SANTURIO, J.M.; MALLMANN, C.A.; BALDISSERA, M.A.; ALMEIDA, C.A.A.; POZZOBON, M.C.; SCHNEIDER, L.G. Qualidade micotoxicológica do milho, sorgo e rações produzidos no Brasil. In: CONGRESSO NACIONAL DE MILHO E SORGO, 21, Londrina, 1996. Resumos. Londrina: Iapar, 1996. p.340. 
SANTURIO, J.M.; REGINATTO, M.; KRACKER, C.; SURDI, G.; TONI, J. de; KRAKER, J.; MALLMANN, C.A. Desempenho de perus de corte alimentados com níveis crescentes de aflatoxinas, com ou sem adição de adsorvente. Ciência Rural, v.28, n.1, p.111-117, 1998.

SCOTT, P.M. Effects of food processing on mycotoxins. Journal of Food Protection, v.47, n.6, p.489-499, 1984.

SCOTT, P.M. Effects of processing and detoxification treatments on ochratoxin A: introduction. Food Additives and Contaminants, v.13, p.19-21, 1996. Suppl.

SCUSSEL, V.M.; RODRIGUEZ-AMAIA, D.B.; SILVA, W.J. da. Incidência de aflatoxinas em milho (Zea mays L.) e em seus produtos derivados, comercializados na região de Campinas, estado de São Paulo, Brasil. Ciência e Tecnologia de Alimentos. v.6, n.1, p.75-85, 1986.

SHANTHA, T.; MURTHY, V.S.; RATI, E.R.; PREMA, V. Detoxification of groundnut seeds by urea and sunlight. Journal of Food Safety, v.7, p.225-231, 1986.

SHERWOOD, R.F.; PEBERDY, J.F. Production of the mycotoxin, zearalenone, by Fusarium graminearum growing on stored grain i. grain storage at reduced temperatures. Journal of the Science of Food and Agriculture, v.25, p.1081-1087, 1974.

SIAME, B.A.; LOVELACE, C.E.A. Effects of temperature on the simultaneous production of zearalenone and deoxynivalenol by Fusarium graminearum on maize. African Crop Science Journal, v.2, n.2, p.189-195, 1994.

SIBANDA, L.; MAROVATSANGA, L.T.; PESTKA, J.J. Review of mycotoxin work in sub-Saharan Africa. Food Control, v.8, n.1, p.21-29, 1997.

SMITH, T.K. Recent advances in the understanding of Fusarium trichothecene mycotoxicoses. Journal of Animal Science, v.70, p.3989-3993, 1992.

SOARES, L.M.V.; RODRIGUEZ-AMAYA, D.B. Survey of aflatoxins, ocratoxin A, zearalenone, and sterigmatocystin in some brasilian foods by using multi-toxin thin-layer chromatographic method. Journal of the Association of Official Analytical Chemists, v.72, n.1, p.22-26, 1989. 
SUBIRADE, I. Fate of ochratoxin A during breadmaking. Food Additives and Contaminants, v.13, p.25-26, 1996. Suppl.

SUTTON, J.C. Epidemiology of wheat head bligth and maize ear rot caused by Fusarium graminearum. Canadian Journal of Plant Pathology, v.4, p.195-209, 1982.

SYDENHAM, E.W.; THIEL, P.G.; MARASAS, W.F.O.; SHERPARD, G.S.; VAN SCHALKWYK, D.J.; KOCH, K.R. Natural occurrence of some Fusarium mycotoxins in corn from low and high oesophageal cancer prevalence areas of the Transkei, Southem Africa. Journal of Agriculture and Food Chemistry, v.38, n.10, p.1900-1903, 1990.

THIESEN, J. Detoxification of aflatoxins in groundnut meal. Animal Feed Science Technology, v.2, p.67-75, 1977.

TRENK, H.L.; BUTZ, M.E.; CHU, F.S. Production of ochratoxins in different cereal products by Aspergillus ochraceus. Applied Microbiology, v.21, p.1032-1035, 1971.

TUITE, J.; SHANER, G.; RAMBO, G.; FOSTER, J.; CALDWELL, R.W. The Gibberella ear rot epidemics of corn in Indiana in 1965 and 1972. Cereal Science Today, v.19, p.238-241, 1974.

WILLIAMS, R.J.; McDONALD, D. Grain molds in the tropics: problems and importance. Annual Review of Phytopathology, v.21, p.153-178, 1983.

ZUBER, M.S.; LILLEHOJ, E.B. Status of the aflatoxin problem in corn. Journal Environmental Quality, v.8, p.1-5, 1979. 